\title{
Effect of supplementing essential fatty acids to pregnant nonlactating Holstein cows and their preweaned calves on calf performance, immune response, and health
}

\author{
M. Garcia, ${ }^{*}$ L. F. Greco, ${ }^{*}$ M. G. Favoreto, ${ }^{*}$ R. S. Marsola, ${ }^{*}$ D. Wang, ${ }^{*}$ J. H. Shin, ${ }^{*}$ E. Block, $\dagger$ W. W. Thatcher, ${ }^{*}$ \\ J. E. P. Santos, ${ }^{*}$ and C. R. Staples ${ }^{* 1}$ \\ *Department of Animal Sciences, University of Florida, Gainesville 32608 \\ †Arm and Hammer Animal Nutrition, Princeton, NJ 08543
}

\section{ABSTRACT}

The objective was to evaluate the effect of supplementing saturated or unsaturated fatty acids (FA) during late gestation of cows and during the preweaning period of calves on growth, health, and immune responses of calves. During the last 8 wk of pregnancy, Holstein cattle $(\mathrm{n}=96)$ were fed no fat supplement (control), a saturated FA (SFA) supplement enriched in C18:0, or an unsaturated FA supplement enriched in the essential FA linoleic acid. Newborn calves were fed a milk replacer (MR) with either low linoleic acid (LLA; coconut oil) or high linoleic acid (HLA; coconut oil and porcine lard) concentration as the sole feedstuff during the first $30 \mathrm{~d}$. A grain mix with minimal linoleic acid was offered between 31 and $60 \mathrm{~d}$ of life. At 30 and 60 $\mathrm{d}$ of life, concentrations of linoleic acid in plasma were increased in calves born from dams supplemented with essential FA compared with SFA (44.0 vs. $42.5 \%$ of total FA) and in calves consuming HLA compared with LLA MR (46.3 vs. $40.8 \%$ of total FA). Total n-3 FA concentration was increased in plasma of calves fed HLA compared with LLA MR (1.44 vs. 1.32\%) primarily due to increased $\alpha$-linolenic acid. Prepartum supplementation with SFA tended to improve dry matter intake (48.8 vs. $46.7 \mathrm{~kg}$ ) and improved average daily gain (0.50 vs. $0.46 \mathrm{~kg} / \mathrm{d}$ ) by calves without affecting efficiency of gain or circulating concentrations of anabolic metabolites or hormones. Increasing mean intake of linoleic acid from approximately 4.6 to $11.0 \mathrm{~g} / \mathrm{d}$ during the first $60 \mathrm{~d}$ of life increased average daily gain $(0.50$ vs. $0.45 \mathrm{~kg} / \mathrm{d})$ without a change in dry matter intake, thus improving feed efficiency ( 0.63 vs. $0.59 \mathrm{~kg}$ of gain $/ \mathrm{kg}$ of dry matter intake). Improved weight gain in calves fed HLA MR was accompanied by increased or tendency to increase plasma concentrations of glucose (92.7 vs. $89.9 \mathrm{~g} / \mathrm{dL}$ ) and insulin-like growth factor I ( 59.5 vs. $53.2 \mathrm{~g} / \mathrm{dL})$, in-

Received September 9, 2013.

Accepted March 15, 2014.

${ }^{1}$ Corresponding author: chasstap@ufl.edu creased hematocrit (36.0 vs. $34.4 \%$ ) and concentration of blood lymphocytes ( 4.61 vs. $4.21 \times 10^{3} / \mu \mathrm{L}$ ), lowered plasma concentrations of acid-soluble protein (78.8 vs. $91.3 \mathrm{mg} / \mathrm{L})$ and blood platelets (736 vs. $822 \times 10^{3} /$ $\mu \mathrm{L}$ ), and increased production of IFN- $\gamma$ by peripheral blood mononuclear cells at $30 \mathrm{~d}$ of age (48.1 vs. 25.6 $\mathrm{pg} / \mathrm{mL}$ ), possibly indicating an earlier development of the immune system. Partial replacement of coconut oil with porcine lard in MR improved calf performance and some aspects of immunity.

Key words: calf, linoleic acid, growth, immunity

\section{INTRODUCTION}

The essentiality of linoleic acid was discovered by Burr and Burr (1930) in pioneer studies performed with rats fed fat-free diets and supplemented with chemically methylated linoleic acid or linoleic acid in naturally occurring oils. Those authors identified the symptoms of long-term linoleic acid deficiency, specifically poor growth, dermatitis, poor reproduction, and death. Later, a serum ratio of C20:3n-9 to C20:4n- 6 exceeding 0.2 was recommended as an indicator of linoleic acid deficiency in humans (Holman, 1978). However 13 yr later, the same author (Holman et al., 1991) cautioned researchers of applying the C20:3n-9to-C20:4n-6 ratio as a sole index of essential FA (EFA) status. Recently, the historical research quantifying the linoleic acid requirement has been called into question because investigators did not include $\alpha$-linolenic acid in the experimental diets, which likely made the diets deficient in 2 FA (Cunnane and Guesnet, 2011). In addition, efforts should be made to establish FA intakes that optimize animal health rather than identifying minimal amounts that are sufficient only for growth (Cunnane and Guesnet, 2011).

Dairy calves fed increasing amounts of linoleic acid in their milk replacer ( $\mathbf{M R}$ ) had increased linoleic acid concentration in various lipid classes of plasma, but ADG did not reflect intake of linoleic acid (Jenkins et al. 1985; Jenkins and Kramer, 1986). Likewise, beef 
calves suckling cows fed diets containing high-linoleate safflower seeds (11.8\% of dietary DM) had greater plasma concentrations of linoleic acid (Lake et al., 2006b) and glucose (Lake et al., 2006a) compared with those fed no oilseeds or high-oleate safflower seeds; however, ADG was unchanged (Lake et al., 2005). It is very possible that calf performance was unaffected in those studies by increased intake of linoleic acid because control calves were of adequate linoleic acid status. If calves received sufficient amounts of linoleic acid in utero, from colostrum consumption, or from their basal diet after birth, or a combination of them, benefits from consuming more linoleic acid would not be realized. These studies evaluated increasing intake of linoleic acid on calf performance but did little to evaluate the effect of dietary linoleic acid on circulating concentrations of metabolites and markers of immunity as well as symptoms of diseases. With the increased knowledge of the metabolism and mechanisms of action of linoleic acid, such as its apparent proinflammatory effect (Calder, 2005), future research with EFA should include effects on health and immunity. Recent studies (Ballou and DePeters, 2008; Ballou et al., 2008) have focused on the effect of dietary n-3 FA on different aspects of functional immunocompetence and health of preweaned dairy calves, whereas similar research involving $\mathrm{n}-6 \mathrm{FA}$ is lacking. In a recent review article, Jacobi and Odle (2012) discussed the potential benefits of including medium-chain FA or PUFA in milk on intestinal health of neonates. Including PUFA in the milk formula for piglets after an intestinal insult improved digestive recovery more rapidly than in piglets fed C16:0 and C18:1n-9; feeding C20:4n-6 had particularly beneficial healing effects on the gut.

Changing formulations of the dam diet toward the end of gestation can influence the metabolic profile and immune status of the newborn calf. Feeding more energy to pregnant Holstein cows during the last $3 \mathrm{wk}$ of gestation increased concentrations of blood glucose and phagocytosis by blood neutrophils of calves and decreased concentrations of blood haptoglobin of calves in the first week of life (Osorio et al., 2013). The type of energy fed prepartum, specifically the FA profile of the energy supplement, may influence the metabolism of the newborn calf.

Therefore, our hypothesis was that calves born to dams not supplemented with EFA in late gestation would respond (improved health and growth) to a greater extent to EFA supplementation than calves born to dams fed diets supplemented with EFA. The objective was to determine whether intake of energy and or of differing long-chain FA in late gestation would influence metabolic profile, immune status, health, and growth of calves consuming diets enriched in medium- chain FA or EFA (primarily linoleic acid) during the first 2 mo of life.

\section{MATERIALS AND METHODS}

\section{Prepartum Diets and Adult Cattle Management}

The experiment was approved by the University of Florida Animal Research Committee (Gainesville) and conducted at the University of Florida dairy farm. Pregnant nulliparous $(\mathrm{n}=35)$ and previously parous $(\mathrm{n}=61)$ Holstein animals were blocked by parity and enrolled in the study starting at $8 \mathrm{wk}$ before their calculated parturition date.

The basal prepartum diet was formulated to have low concentrations of total FA (1.87\% of DM), linoleic acid $(0.38 \%$ of $\mathrm{DM})$, and $\alpha$-linolenic acid $(0.21 \%$ of $\mathrm{DM}$; Table 1). Prepartum cattle were fed 1 of the following 3 diets: (1) no fat supplement (control), (2) 1.7\% of dietary DM as SFA supplement (Energy Booster 100; Milk Specialties Co., Dundee, IL), or (3) $2.0 \%$ of dietary DM as Ca salts of FA enriched with EFA supplement (Megalac R; Church \& Dwight Co. Inc., Princeton, NJ). The proportion of C18:0 in the SFA supplement was $49.9 \%$, whereas linoleic and $\alpha$-linolenic acids were not detected (Table 2). The EFA supplement contained 4.5\% C18:0, 27.4\% linoleic acid, and 2.3\% $\alpha$-linolenic acid (total FA basis; Table 2). The concentration of C16:0 was similar in both fat supplements (Table 2). Dietary concentrations of C18:0 were $0.06,0.86$, and $0.14 \%$; of linoleic acid were $0.38,0.37$, and $0.83 \%$; and of $\alpha$-linolenic acid were $0.21,0.21$, and $0.24 \%$ (DM basis) in control, SFA, and EFA diets, respectively (Table 1). Fat supplements partially replaced citrus pulp. The diets containing SFA and EFA supplements were isocaloric and greater than that of the control diet. All diets were isonitrogenous (Table 1). Prepartum housing and feeding management practices were described in Garcia et al. (2014).

\section{Preweaning Diets and Calves Management}

Pregnant animals were monitored for signs of initiating parturition every $30 \mathrm{~min}$ between 0530 to $1530 \mathrm{~h}$ and then every $2 \mathrm{~h}$ between 1530 and $0530 \mathrm{~h}$. Within $3 \mathrm{~h}$ of birth, calves were weighed, ear tagged, and the umbilical cord was disinfected with $10 \%$ Betadine solution (Purdue Frederick Co., Norwalk, CT). Calves were housed temporarily in individual pens $(1 \times 1 \mathrm{~m})$ equipped with a heat lamp before moving to individual wire enclosures $(1 \times 1.5 \mathrm{~m})$ bedded with sand, between 6 to $16 \mathrm{~h}$ of age.

Within $2 \mathrm{~h}$ of birth, dams were milked with a cowside vacuum pump. Colostrum quality was recorded using 
Table 1. Ingredient and chemical composition of experimental diets fed to pregnant Holstein animals starting 8 wk before calculated parturition date

\begin{tabular}{|c|c|c|c|}
\hline \multirow[b]{2}{*}{ Item } & \multicolumn{3}{|c|}{ Prepartum diet ${ }^{1}$} \\
\hline & Control & SFA & EFA \\
\hline \multicolumn{4}{|c|}{ Ingredient, $\%$ of DM } \\
\hline Bermuda silage & 56.0 & 56.0 & 56.0 \\
\hline Ground barley & 8.0 & 8.0 & 8.0 \\
\hline Peanut meal & 10.0 & 10.0 & 10.0 \\
\hline Citrus pulp & 21.9 & 20.2 & 19.9 \\
\hline SFA & - & 1.7 & - \\
\hline Ca salts of FA & - & - & 2.0 \\
\hline Mineral mix $^{2}$ & 4.1 & 4.1 & 4.1 \\
\hline \multicolumn{4}{|c|}{ Nutrient composition, DM basis } \\
\hline $\mathrm{NE}_{\mathrm{L}},{ }^{3} \mathrm{Mcal} / \mathrm{kg}$ & 1.42 & 1.49 & 1.50 \\
\hline $\mathrm{CP}, \%$ & 14.0 & 13.9 & 14.1 \\
\hline NDF, $\%$ & 47.0 & 48.2 & 47.4 \\
\hline $\mathrm{ADF}, \%$ & 25.6 & 25.3 & 25.5 \\
\hline FA, $\%$ & 1.87 & 3.42 & 3.50 \\
\hline C18:0, \% & 0.06 & 0.86 & 0.14 \\
\hline $\mathrm{C} 18: 2 \mathrm{n}-6, \%$ & 0.38 & 0.37 & 0.83 \\
\hline $\mathrm{C} 18: 3 \mathrm{n}-3, \%$ & 0.21 & 0.21 & 0.24 \\
\hline $\mathrm{Ca}, \%$ & 1.41 & 1.47 & 1.67 \\
\hline $\mathrm{P}, \%$ & 0.29 & 0.28 & 0.30 \\
\hline $\mathrm{Mg}, \%$ & 0.38 & 0.38 & 0.41 \\
\hline $\mathrm{K}, \%$ & 1.35 & 1.34 & 1.34 \\
\hline $\mathrm{Cl}, \%$ & 0.76 & 0.76 & 0.80 \\
\hline $\mathrm{Na}, \%$ & 0.17 & 0.17 & 0.20 \\
\hline
\end{tabular}

${ }^{1}$ Control $=$ no fat supplement; SFA $=$ SFA supplement; EFA = essential FA supplement.

${ }^{2}$ Contains (DM basis) $34.5 \%$ corn meal, $5.0 \%$ dicalcium phosphate, $16.0 \%$ calcium carbonate, $10 \%$ calcium sulfate, $5 \%$ magnesium oxide, $10 \%$ magnesium sulfate, $4 \%$ sodium chloride, $1.7 \%$ Zinpro 4-plex (Zinpro Corp., Minneapolis, MN), 0.4\% Rumensin 80 (Elanco Animal Health, Greenfield, IN), 0.35\% Sel-Plex 2000 (Alltech Biotechnology, Nicholasville, KY), $0.002 \%$ Ca iodate, and a vitamin premix. Each kilogram contains $24.5 \%$ CP, $9.8 \% \mathrm{Ca}, 1.5 \% \mathrm{P}, 4.2 \% \mathrm{Mg}, 3.2 \% \mathrm{~S}, 1.7 \% \mathrm{Na}, 10.7 \% \mathrm{Cl}, 475 \mathrm{mg}$ of $\mathrm{Zn}, 160 \mathrm{mg}$ of Cu, $456 \mathrm{mg}$ of $\mathrm{Mn}, 7.4$ $\mathrm{mg}$ of Se, $37.4 \mathrm{mg}$ of Co, $13.2 \mathrm{mg}$ of I, 118,000 IU of vitamin A, 27,500 IU of vitamin D, 2,600 IU of vitamin $\mathrm{E}$, and $770 \mathrm{mg}$ of monensin.

${ }^{3}$ Net energy of diets calculated using $12 \mathrm{~kg} / \mathrm{d}$ of DMI (CPM-Dairy software; University of Pennsylvania, Kennett Square, PA).

a colostrometer (Biogenics, Mapleton, OR) and later verified by radioimmunodiffusion analysis as detailed in Garcia et al. (2014). Immediately after weighing, calves were given $4 \mathrm{~L}$ of colostrum from their own dam, regardless of IgG concentration, using an esophageal feeding tube. When a dam did not produce sufficient

Table 2. Fatty acid profile of prepartum fat supplements and diets, milk replacers, and calf grain mix

\begin{tabular}{|c|c|c|c|c|c|c|c|c|}
\hline $\begin{array}{l}\mathrm{FA}, \mathrm{g} / 100 \mathrm{~g} \\
\text { of total FA }\end{array}$ & \multicolumn{2}{|c|}{ Fat supplement $^{1}$} & \multicolumn{3}{|c|}{ Prepartum diet } & \multicolumn{2}{|c|}{ Milk replacer ${ }^{2}$} & $\begin{array}{c}\text { Grain } \\
\text { mix }\end{array}$ \\
\hline C8:0 & 0.8 & $\mathrm{ND}^{3}$ & ND & 0.4 & ND & 8.5 & 6.2 & ND \\
\hline C12:0 & 0.7 & 0.3 & ND & 0.3 & 0.2 & 42.5 & 29.9 & 0.1 \\
\hline C14:0 & 4.6 & 0.8 & 0.4 & 2.4 & 0.5 & 15.9 & 11.9 & 0.2 \\
\hline C16:0 & 36.2 & 34.3 & 19.9 & 27.6 & 26.9 & 10.5 & 14.6 & 13.2 \\
\hline C18:0 & 49.9 & 4.5 & 3.4 & 25.1 & 3.9 & 4.4 & 6.7 & 2.0 \\
\hline C18:1 & ND & 27.1 & 37.7 & 19.9 & 32.4 & 8.8 & 15.7 & 47.1 \\
\hline C18:2n-6 & ND & 27.4 & 20.5 & 10.9 & 23.8 & 2.9 & 9.0 & 28.2 \\
\hline C18:3n-3 & ND & 2.3 & 11.0 & 6.0 & 7.0 & ND & 0.8 & 2.1 \\
\hline C20:0 & 0.8 & 0.3 & 1.0 & 0.9 & 0.7 & ND & ND & 0.7 \\
\hline Others & 4.8 & 2.8 & 5.5 & 5.2 & 4.2 & 0 & 0 & 6.2 \\
\hline
\end{tabular}

${ }^{1}$ Fat supplements for prepartum diets: SFA supplement [Energy Booster 100 (Milk Specialties Co., Dundee, IL)] and essential FA (EFA) supplement [Megalac-R (Church \& Dwight Co. Inc., Princeton, NJ)].

${ }^{2}$ Milk replacers are defined as low linoleic acid (LLA) and high linoleic acid (HLA).

${ }^{3} \mathrm{ND}=$ not detected. 
colostrum for her calf, colostrum from another dam fed the same prepartum treatment was used to feed that calf. Excess colostrum $(>1 \mathrm{~L}$ and $>50 \mathrm{~g}$ of $\mathrm{IgG} / \mathrm{L})$ after calf feeding was stored $\left(-4^{\circ} \mathrm{C}\right)$. The concentration of IgG in serum was measured at 24 to $30 \mathrm{~h}$ after feeding of colostrum using radioimmunodiffusion (Garcia et al., 2014).

Calves were blocked by sex $(\mathrm{n}=56$ females and 40 males) and dam diet and randomly assigned to receive an MR (Land O'Lakes, Webster City, IA; Tables 2 and 3) containing low (LLA; $0.48 \%$ linoleic acid, DM basis or $2.9 \%$ linoleic acid, FA basis) or high concentrations of linoleic acid (HLA; $1.54 \%$ linoleic acid, DM basis or $9.0 \%$, FA basis) for $60 \mathrm{~d}$ starting at birth. Coconut oil (CCO) was the sole fat source in the LLA MR, whereas a mixture of $\mathrm{CCO}$ and porcine lard were the fat sources in the HLA MR. Porcine lard supplied a small amount of $\alpha$-linolenic acid to the HLA MR that otherwise was not present in CCO. Rats do not have a published requirement for $\alpha$-linolenic acid but daily recommendations are published for humans [EFSA Panel on Dietetic Products, Nutrition, and Allergies (NDA), 2010]. The expected daily intake of $\alpha$-linolenic of calves fed HLA MR would provide about $40 \%$ of the intake recommended for humans.

Milk replacers were fed at 0600 and $1230 \mathrm{~h}$ daily at a constant rate of $32 \mathrm{~g}$ of $\mathrm{DM} / \mathrm{kg}$ of $\mathrm{BW}^{0.75}$ throughout the 60-d experiment. This feeding rate was selected in order for LLA-fed calves to consume less linoleic acid than would be consumed by calves fed traditional amounts of whole milk in a commercial setting. Calves consuming 3.79 L of whole milk with $3.0 \%$ FA, of which $3.1 \%$ of the FA is linoleic acid, would consume $3.5 \mathrm{~g}$ of linoleic acid/d. Holstein calves weighing $40 \mathrm{~kg}$ in the current study would be offered 2.5 or $7.8 \mathrm{~g}$ of linoleic acid daily (0.15 or $0.49 \mathrm{~g}$ of linoleic acid $/ \mathrm{kg}$ of $\mathrm{BW}^{0.75}$ ) when fed LLA or HLA MR, respectively. The linoleic acid offered from the LLA MR was below the minimum recommended intake of $0.21 \mathrm{~g}$ of linoleic acid $/ \mathrm{kg}$ of $\mathrm{BW}^{0.75}$ for $100 \mathrm{~g}$ female rats consuming 65.6 $\mathrm{kcal}$ of ME/d (NRC, 1995). Intake of linoleic acid by calves fed the HLA MR is commercially feasible. The MR were formulated to be isolipidic, isocaloric, and isonitrogenous (Table 3$)$. Warm water $\left(38\right.$ to $\left.42^{\circ} \mathrm{C}\right)$ was added to the MR powder at the time of each feeding to prepare a MR of $11 \%$ DM. Calves were weighed weekly and amounts of MR powder fed were adjusted based upon weekly BW. Refusal of MR was recorded daily.

A single grain mix (1.0\% linoleic acid, DM basis; Tables 2 and 3) was offered in ad libitum amounts from 31 to $60 \mathrm{~d}$ of age. Barley and peanut meal were chosen as ingredients in the grain mix because of their low linoleic acid concentration. Peanut meal contained 2 $\mu \mathrm{g} / \mathrm{kg}$ of aflatoxin (Quanta Lab, Selma, TX). Amounts
Table 3. Ingredient and chemical composition of milk replacers and grain mix

\begin{tabular}{lccc}
\hline & \multicolumn{2}{c}{ Milk replacer $^{1}$} & \\
\cline { 2 - 3 } Item & LLA $^{2}$ & HLA $^{3}$ & $\begin{array}{c}\text { Grain } \\
\text { mix }\end{array}$ \\
\hline Ingredient, \% of DM & & & \\
Barley (ground) & - & - & 51.7 \\
Peanut meal & - & - & 16.5 \\
Beet pulp shreds & - & - & 24.5 \\
Sugarcane molasses & - & - & 5.3 \\
Mineral mix & - & - & 2.0 \\
Nutrient, DM basis & & & \\
Lactose, \% & 34.1 & 34.2 & - \\
Protein, \% & 29.0 & 28.7 & 18.7 \\
FA, \% & 16.6 & 17.1 & 3.4 \\
NDF, \% & - & - & 23.0 \\
Ca, \% & 0.8 & 0.8 & 0.5 \\
P, \% & 0.8 & 0.8 & 0.5 \\
Mg, \% & 0.1 & 0.1 & 0.4 \\
K, \% & 2.4 & 2.4 & 0.9 \\
Na, \% & 1.2 & 1.2 & 0.2 \\
S, \% & 0.4 & 0.4 & 0.2 \\
Fe, mg/kg & 96.7 & 110.3 & 440.0 \\
Zn, mg/kg & 40.3 & 41.3 & 55.5 \\
Cu, mg/kg & 8.3 & 6.8 & 14.5 \\
Mn, mg/kg & 49.0 & 47.8 & 46.5 \\
Mo, mg/kg & 1.4 & 1.3 & 2.8 \\
Co, mg/kg & 0.5 & 0.6 & - \\
\hline
\end{tabular}

${ }^{1}$ Milk replacers were defined as low linoleic acid (LLA) and high linoleic acid (HLA).

${ }^{2}$ Milk replacer was prepared by Land O'Lakes (Webster City, IA) and contained prehomogenized coconut oil $(30.5 \%)$, milk derivate products (68.6\%), Neo-Terramycin 100/50 (0.1\%), and vitamin and mineral mixes $(0.8 \%$, as-is basis). Each kilogram contained $0.90 \% \mathrm{Ca}, 0.87 \% \mathrm{P}$, $0.1 \mathrm{mg}$ of $\mathrm{Co}, 10.1 \mathrm{mg}$ of $\mathrm{Cu}, 1.0 \mathrm{mg}$ of I, $100 \mathrm{mg}$ of Fe, 45,374 IU of vitamin A, 11,345 IU of vitamin D, and $220 \mathrm{IU}$ of vitamin $\mathrm{E}$ (as-is basis). ${ }^{3}$ Milk replacer was prepared by Land O'Lakes and contained prehomogenized coconut oil (13.3\%) and porcine lard (19.6\%), milk derivate products $(66.3 \%)$, Neo-Terramycin 100/50 (0.1\%), and vitamin and mineral mixes $(0.7 \%$, as-is basis $)$. Each kilogram of MR contained $0.90 \% \mathrm{Ca}, 0.87 \% \mathrm{P}, 0.1 \mathrm{mg}$ of Co, $10.1 \mathrm{mg}$ of $\mathrm{Cu}, 1.0 \mathrm{mg}$ of I, $100 \mathrm{mg}$ of Fe, 45,374 IU of vitamin A, 11,345 IU of vitamin D and $220 \mathrm{IU}$ of vitamin $\mathrm{E}$ (as-is basis).

${ }^{4}$ Each kilogram contained $8.8 \% \mathrm{Ca}, 4.2 \% \mathrm{P}, 11.4 \% \mathrm{Mg}, 12.4 \% \mathrm{Cl}$, $0.49 \% \mathrm{~K}, 8.1 \% \mathrm{Na}, 0.36 \% \mathrm{~S}, 58 \mathrm{mg}$ of $\mathrm{Co}, 263 \mathrm{mg}$ of $\mathrm{Cu}, 26 \mathrm{mg}$ of I, $1,933 \mathrm{mg}$ of Fe, $923 \mathrm{mg}$ of $\mathrm{Mn}, 8.46 \mathrm{mg}$ of Se, 1,109 $\mathrm{mg}$ of Zn, 259,000 IU of vitamin A, 70,000 IU of vitamin D, and 2,400 IU of vitamin $\mathrm{E}$ (DM basis).

of grain mix offered and refused were measured daily. Clean water was available at all times. Body weights for monitoring weight gain were taken before colostrum feeding and at 30 and $60 \mathrm{~d}$ before the morning feeding of MR. Within 2 to $4 \mathrm{~h}$ after the first daily feeding of $\mathrm{MR}$, attitude and fecal scores were recorded for each calf according to Magalhães et al. (2008). Attitude scores recorded were (1) responsive, (2) nonactive, (3) depressed, or (4) moribund. Fecal consistency scores recorded were (1) firm, no diarrhea; (2) moderate, soft, no diarrhea; (3) runny feces, mild diarrhea; or (4) watery feces, diarrhea.

Calves were vaccinated according to the farm's vaccination protocol. Calves experiencing diarrhea (fecal 
score $>2$ ) were given electrolytes (Gener-Lyte; Bio-Vet Inc., Blue Mound, WI), bismuth subsalicylate (Bismusol; First Priority Inc., Elgin, IL), and sulfadimethoxine (Albon boluses; Pfizer Co., New York, NY) for $5 \mathrm{~d}$. If the diarrheic condition reoccurred in a given calf, the same treatment was readministered. Use of proinflammatory drugs were avoided, with the exception of 3 calves that were treated with Flunixin meglumine (Banamine; Merck \& Co. Inc., Summit, NJ) at 1, 58, and $58 \mathrm{~d}$ of age, respectively. Calves given Flunixin meglumine were not included in immune response analyses during the periods of drug clearance. One calf was diagnosed with chronic pneumonia and was removed from the study at $38 \mathrm{~d}$ of age. The rectal temperature of sick calves only was measured. Fever was defined as a rectal temperature $\geq 39.5^{\circ} \mathrm{C}$.

\section{Hormone and Metabolite Analyses}

Blood samples ( $\sim 16 \mathrm{~mL}$ per sample) were collected from the jugular vein using a tube without anticoagulant and one containing $\mathrm{K}_{2} \mathrm{EDTA}$ (Vacutainer; Becton, Dickinson and Co., Franklin Lakes, NJ) at 24 to $30 \mathrm{~h}$ of life and then on $4,8,11,15,18,22,25,29,36,42$, 49 , and $56 \pm 1 \mathrm{~d}$ of age. An additional blood sample $(\sim 8 \mathrm{~mL})$ was collected via jugular vein without anticoagulant before colostrum feeding ( 0 to $2 \mathrm{~h}$ of life). Hematocrit was measured by microcentrifugation (Microspin 24 tube micro hematocrit centrifuge; Vulcon Technologies Inc., Grandview, MO). Plasma and serum were separated from cells by centrifugation at $2,095 \times g$ for 15 min at $4^{\circ} \mathrm{C}$ (Allegra X-15R centrifuge; Beckman Coulter Inc., Brea, CA) and stored at $-20^{\circ} \mathrm{C}$. Before freezing, serum was analyzed for total protein (STP), using an automatic temperature-compensated hand refractometer (Reichert Jung; Cambridge Instruments Inc., Buffalo, NY).

Concentrations of glucose and total cholesterol were analyzed in all 13 available plasma samples starting with that taken at 24 to $30 \mathrm{~h}$ of life. In addition, the serum sample taken at 0 to $2 \mathrm{~h}$ of life was analyzed for total cholesterol. Concentrations of NEFA and BHBA were measured in plasma samples at 24 to $30 \mathrm{~h}$ of life, and at $8,15,22,29,36,42,49$, and $56 \pm 1 \mathrm{~d}$ of age. Serum at 0 to $2 \mathrm{~h}$ of life and plasma at 24 to $30 \mathrm{~h}$ of life and at $15,29,42$, and $56 \pm 1 \mathrm{~d}$ of age were analyzed for insulin and IGF-I.

Concentrations of plasma glucose and urea N (PUN) were analyzed using a Technicon Autoanalyzer (Technicon Instruments Corp., Chauncey, NY) by the method of Bran and Luebbe Industrial Method 339-19 (Gochman and Schmitz, 1972) and Bran and Luebbe Industrial Method 339-01 (Marsh et al., 1965), respectively. Intraassay and interassay coefficients of variation were
2.25 and $3.87 \%$ and 1.65 and $3.16 \%$ for glucose and PUN, respectively. Concentrations of NEFA in plasma were determined using a commercial kit (NEFA-HR kit; Wako Diagnostics Inc., Richmond, VA), modified according to Johnson and Peters (1993). The intraassay coefficient of variation was $2.2 \%$. Concentrations of BHBA in plasma were determined using a commercial kit (Wako Autokit 3-HB; Wako Diagnostics Inc.). Intraassay and interassay coefficients of variation for BHBA were 3.5 and $5.9 \%$, respectively. Concentrations of total cholesterol in plasma were determined using a commercial kit (Cholesterol E kit; Wako Diagnostics Inc.). Intraassay and interassay coefficients of variation for total cholesterol were 2.5 and $4.8 \%$, respectively. Concentrations of IGF-I in plasma were determined using a human-specific commercial ELISA kit with $100 \%$ cross-reactivity with bovine IGF-I (active non-extraction IGF-I ELISA; Diagnostic Systems Laboratory Inc. Webster, TX), following the manufacturer's protocol. Intraplate and interplate coefficients of variation for IGF-1 were 2.4 and $3.2 \%$, respectively. Concentrations of insulin in plasma were determined using a doubleantibody RIA (Badinga et al., 1991). Intraassay and interassay coefficients of variation were 7.3 and $14.6 \%$, respectively.

The total FA extraction from feed $(500 \mathrm{mg}$, as-fed basis) and plasma $(1.5 \mathrm{~mL})$ samples was performed by the 2-step methylation procedure $(0.5 \mathrm{M}$ sodium methoxide and 5\% methanolic $\mathrm{HCl}$ ) according to Kramer et al. (1997). One milliliter of internal standard (C19:0; 1 $\mathrm{mg} / \mathrm{mL}$ of benzene) was added to calculate the total FA concentration. The individual FAME were determined using a Varian CP-3800 gas chromatograph (Varian Inc., Palo Alto, CA) equipped with autosampler (Varian CP-8400; Varian Inc.), flame ionization detector, and a Varian capillary column (CP-Sil 88, $100 \mathrm{~m} \times 0.25$ $\mathrm{mm} \times 0.2 \mu \mathrm{m}$; Varian Inc.). The carrier gas was He, the split ratio was 10:1, and the injector and detector temperatures were maintained at $250^{\circ} \mathrm{C}$. One microliter of sample was injected via the autosampler into the column. The oven temperature was set initially at $120^{\circ} \mathrm{C}$ for $1 \mathrm{~min}$, increased by $5^{\circ} \mathrm{C} / \mathrm{min}$ up to $190^{\circ} \mathrm{C}$, held at $190^{\circ} \mathrm{C}$ for $30 \mathrm{~min}$, increased by $2^{\circ} \mathrm{C} / \mathrm{min}$ up to $220^{\circ} \mathrm{C}$, and held at $220^{\circ} \mathrm{C}$ for $15 \mathrm{~min}$. Each peak was identified and peak area calculated based on the retention time and peak area of purchased, known standards (Matreya LLC, Pleasant Gap, PA).

\section{Acute-Phase Proteins, Adhesion Molecules of Neutrophils, and Neutrophil Phagocytosis}

Concentrations of haptoglobin $(\mathbf{H p})$ and acid-soluble protein (ASP) in plasma were determined in all samples collected using $\mathrm{K}_{2}$ EDTA as an anticoagulant. 
Plasma Hp concentration was determined by measuring the differences of hydrogen peroxide activity with Hp-hemoglobin complex (Makimura and Suzuki, 1982). Concentrations of $\mathrm{Hp}$ are reported as arbitrary units (optical density $\times 100$ ) resulting from absorption at $450 \mathrm{~nm}$. Intraassay and interassay coefficients of variation were 6.0 and $10.9 \%$, respectively. Concentrations of ASP were extracted from plasma using 0.6 $M$ perchloric acid and analyzed with the bicinchoninic acid kit (Sigma-Aldrich, St. Louis, MO). The intraassay and interassay coefficients of variation were 2.6 and $5.9 \%$, respectively.

Blood (10 mL; heparin Vacutainers; Becton, Dickinson and Co.) cell types were quantified using a Bayer Advia 120 cell counter (Fisher Diagnostics, Middletown, VA) at 2, 7, 14, 21, 29, 40, and $60 \pm 1 \mathrm{~d}$ of age. Expressions of 2 adhesion molecules for neutrophils were quantified (Silvestre et al., 2011). The antibodies were a monoclonal mouse anti-bovine L-selectin (CD62L, IgG1 isotype; AbD Serotec, Raleigh, NC) and a mouse anti-canine $\beta_{2}$ integrin (CD18, IgG1 isotype; AbD Serotec) that cross-reacts with bovine CD18. Additionally, an isotype mouse control antibody (IgG1 isotype; AbD Serotec) was used to correct for nonspecific binding of CD62L and CD18 antibodies to the cells. For each sample, the optical features of 50,000 neutrophils were acquired using a FACSort flow cytometer equipped with a 488-nm argon ion laser for excitation at $15 \mathrm{~mW}$ (BD Biosciences, San Jose, CA) equipped with CellQuest software (Becton Dickinson, San Jose, CA). Density cytograms were generated by linear amplification of the signals in forward (cell diameter) and side (membrane irregularity) scatters. Percentages of neutrophil cells testing positively to $\mathrm{CD} 62 \mathrm{~L}$ or $\mathrm{CD} 18$ were determined based upon gated cells. Also, the geometric mean fluorescence intensity (GMFI) of the labeling kit, an indicator of the number of receptors on the surface of each neutrophil cell, was obtained in the histogram for the gated cell populations.

Activation of phagocytic cells was measured using pHrodo Escherichia coli BioParticles Conjugate for phagocytosis (Molecular Probes; Invitrogen Corp., Carlsbad, CA). To measure phagocytosis, heparinized blood $(100 \mu \mathrm{L})$ having a neutrophil concentration $<5$ $\times 10^{3} \mathrm{cell} / \mu \mathrm{L}$ was incubated with and without $40 \mu \mathrm{L}$ of reconstituted pHrodo E. coli BioParticles Conjugate (Molecular Probes; Invitrogen Corp.). For blood samples having greater concentrations of neutrophils, proportional amounts of reconstituted product were added. Tubes were rotated and incubated for $2 \mathrm{~h}$ at $37^{\circ} \mathrm{C}$ and then placed on ice to stop neutrophil activity. Red blood cells were lysed, buffered, centrifuged at $931 \times g$ for $5 \mathrm{~min}$ at room temperature, and FACSFlow sheath fluid (200 $\mu \mathrm{L}$; BD Biosciences) was added to each tube.
The percentage of neutrophils exhibiting fluorescence was correlated with the proportion of neutrophils able to phagocytize E. coli, whereas GMFI was interpreted as mean number of bacteria ingested per neutrophil.

\section{Peripheral Blood Mononuclear Cell Isolation and Cytokine Production}

Isolation of peripheral blood mononuclear cells (PBMC) was done at $15 \pm 2$ and $30 \pm 1 \mathrm{~d}$ of age according to Padua and Hansen (2008). The resulting isolated pellet of PBMC was counted using Trypan blue dye (Sigma-Aldrich) and the exclusion method. The cell suspension was adjusted to $2 \times 10^{6}$ cells/ $\mathrm{mL}$. Cells were suspended in $2 \mathrm{~mL}$, plated in triplicate with modified M-199 medium, and stimulated or not stimulated with $10 \mu \mathrm{g} / \mathrm{mL}$ of concanavalin A (SigmaAldrich) in a 6-well plate (Corning Inc., Corning, NY). Plates were incubated for $48 \mathrm{~h}$ at $37^{\circ} \mathrm{C}$ at $5 \% \mathrm{CO}_{2}$. After incubation, plates were centrifuged at $524 \times g$ for 10 min at room temperature and the supernatant stored at $-80^{\circ} \mathrm{C}$. Interferon- $\gamma$ concentration was determined using the bovine IFN- $\gamma$ DuoSet ELISA development kit (R\&D Systems Inc., Minneapolis, MN). The intraassay coefficient of variation was $9.2 \%$.

\section{Statistical Analyses}

The study was done in a randomized block design, with dietary treatments in a factorial arrangement (3 dam diets and 2 calf $\mathrm{MR} ; \mathrm{n}=6$ treatments). At $8 \mathrm{wk}$ before their calculated calving date, a cohort of cows was blocked weekly and randomly assigned to 1 of 3 diets using parity (nulliparous vs. parous) and BCS. At birth, calves were blocked by dam diet and sex and randomly assigned to receive 1 of 2 MR. Repeated-measurement analysis was conducted using PROC MIXED or PROC GLIMMIX of SAS (SAS Institute 2009). The denominator degrees of freedom were computed using the approximation described by Kenward and Roger (1997), using the following model:

$$
\begin{gathered}
\left.\mathrm{Y}_{\mathrm{ijk} l m}=\mu+\mathrm{D}_{\mathrm{i}}+\mathrm{M}_{\mathrm{j}}+\mathrm{G}_{\mathrm{k}}+\mathrm{C}_{(\mathrm{ijk}}\right)_{1}+(\mathrm{DM})_{\mathrm{ij}} \\
+(\mathrm{DG})_{\mathrm{ik}}+(\mathrm{MG})_{\mathrm{jk}}+(\mathrm{DMG})_{\mathrm{ijk}}+\mathrm{A}_{\mathrm{m}}+\mathrm{DA}_{\mathrm{im}} \\
+\mathrm{MA}_{\mathrm{jm}}+\mathrm{GA}_{\mathrm{km}}+\mathrm{DMA}_{\mathrm{ijm}}+\mathrm{DGA}_{\mathrm{ikm}} \\
+\mathrm{MGA}_{\mathrm{jkm}}+\mathrm{DMGA}_{\mathrm{ijkm}}+\varepsilon_{\mathrm{ijklm}},
\end{gathered}
$$

where $Y_{i j k l m}$ is the observation; $\mu$ is overall mean; $D_{i}$ is the fixed effect of dam diet i (control, SFA, or EFA); $M_{j}$ is the fixed effect of MR j (LLA or HLA); $G_{k}$ is the fixed effect of sex $\mathrm{k}$ (male or female); $\mathrm{C}\left({ }_{\mathrm{ijk}}\right)_{1}$ is the random effect of calf 1 nested within dam diet, MR, 
and sex $(1,2,3, \ldots, \mathrm{n}) ;(\mathrm{DM})_{\mathrm{ij}}$ is the interaction of dam diet $\times \mathrm{MR} ;(\mathrm{DG})_{\mathrm{ik}}$ is the interaction of dam diet $\times \operatorname{sex} ;(M G)_{j k}$ is the interaction of $\mathrm{MR} \times \operatorname{sex} ;(\mathrm{DMG})$ ${ }_{\mathrm{ijk}}$ is the interaction of dam diet $\times \mathrm{MR} \times$ sex; $\mathrm{A}_{\mathrm{m}}$ is the effect of age (days or weeks) $\mathrm{m}(1,2,3, \ldots, \mathrm{n})$; $\mathrm{DA}_{i m}$ is the interaction of dam diet $\times$ age; $\mathrm{MA}_{j \mathrm{~m}}$ is the interaction of $\mathrm{MR} \times$ age; $\mathrm{GA}_{\mathrm{km}}$ is the interaction of sex $\times$ age; $\mathrm{DMA}_{\mathrm{ijm}}$ is the interaction of dam diet $\times \mathrm{MR}$ $\times$ age; $\mathrm{DGA}_{\mathrm{ikm}}$ is the interaction of dam diet $\times$ sex $\times$ age; $\mathrm{MGA}_{\mathrm{jkm}}$ is the interaction of $\mathrm{MR} \times$ sex $\times$ age; $\mathrm{DMGA}_{\mathrm{ijkm}}$ is the interaction of dam diet $\times \mathrm{MR} \times$ sex $\times$ age; and $\varepsilon_{\mathrm{ijk} k m}$ is the residual error. The subject used in the repeated measure was calf nested within dam diet, MR, and sex. For nonrepeated measures, the same model was used after removing the age effect and their interactions.

Continuous data were tested for normality of residuals using the Shapiro-Wilk test (SAS Institute, 2009) and transformation was performed to achieve normality as needed. Data were tested to determine the structure of best fit as indicated by the smallest Schwartz Bayesian information criteria. If repeated measures were taken on unequally spaced intervals, the special power $[\operatorname{sp}($ pow $)]$ covariance structure was used. Different temporal responses to treatments were further examined using the SLICE option of PROC MIXED or GLIMMIX.

Five orthogonal contrasts of dam diet, MR, and interactions were tested. Contrasts testing the effects of dam diet were (1) control versus SFA + EFA (FAT) and (2) SFA versus EFA (FA source, FAS), the contrast testing the effect of MR was (3) HLA versus LLA, and contrasts testing the interactions of dam diet and MR were (4) FAT $\times$ MR (contrasts 1 and 3 ) and (5) FAS $\times$ MR (contrasts 2 and 3). If any 3- or 4-way interaction including the effect of time were not significant $(P>0.25)$, the interaction was excluded from the model and the model was rerun. Differences discussed in the text were significant at $P \leq 0.05$ and tended to be significant at $0.05<P \leq 0.10$.

\section{RESULTS AND DISCUSSION}

\section{FA Concentration and Profile in Plasma}

Due to the differences in linoleic acid content of MR, mean daily intake of linoleic acid during the first 30 $\mathrm{d}$ of age, when MR was the only feed, was 2.4 and $8.0 \mathrm{~g} / \mathrm{d}$ by calves fed LLA and HLA MR, respectively. During the second $30 \mathrm{~d}$ of life, mean intake of linoleic acid from MR and grain mix was 6.9 and $14.0 \mathrm{~g} / \mathrm{d}$ for calves fed LLA and HLA MR, respectively. Mean intake of $\alpha$-linolenic acid during the first $30 \mathrm{~d}$ was 0 and $0.7 \mathrm{~g} / \mathrm{d}$ by calves fed LLA and HLA MR, respectively, and 0.3 and $1.2 \mathrm{~g} / \mathrm{d}$ for calves fed LLA and HLA MR, respectively, for the second $30 \mathrm{~d}$.

The concentration of total FA in plasma was $7.7 \%$ greater in calves fed the LLA compared with the HLA MR $(2.09$ vs. $1.94 \mathrm{mg} / \mathrm{mL}$ of plasma; $P=0.02$; Table 4). However, this effect of MR was detected at 30 but not at $60 \mathrm{~d}$ of age $(\mathrm{MR} \times$ age interaction: $P=0.05)$. Murley et al. (1949) also reported that the concentration of fat in plasma was greater in calves consuming butter oil (high in medium-chain FA similar to CCO) as a fat source in MR compared with calves fed hydrogenated soybean oil. Clearance of FA from the blood may have been greater for calves fed HLA compared with LLA MR. Calves fed HLA MR had a greater expression of the peroxisome proliferator-activated receptor $\alpha$ $(\boldsymbol{P P A R}-\boldsymbol{\alpha})$ gene in liver compared with calves fed LLA MR (M. Garcia, L. F. Greco, W. W. Thatcher, J. E. P. Santos, and C. R. Staples, unpublished data). Recent studies have discussed the effect of PPAR- $\alpha$ in lipid metabolism and prevention of dyslipidemia by enhancing very low-density lipoprotein and triglyceride (TG) clearance, reducing secretion of very low-density lipoprotein, modulating high-density lipoprotein synthesis and remodeling, and synthesis, absorption, reverse transport, and excretion of cholesterol (Duval et al., 2007; Li and Chiang, 2009). As discussed below, calves fed HLA MR had lower concentrations of plasma total cholesterol, which accounts for the greatest proportion of lipids in calves. Two hours after feeding, plasma lipid of preruminant calves (21 d of age) was about $40 \%$ cholesterol esters, $36 \%$ phospholipids, $12 \%$ TG, and $12 \%$ NEFA (Bauchart and Aurousseau, 1981). As expression of PPAR- $\alpha$ is increased, the clearance of total cholesterol and TG from plasma may be increased.

The FA profile of the plasma of calves at $30 \mathrm{~d}$ of age was often different from that at $60 \mathrm{~d}$ of age (Table 4) due to the initiation of grain feeding at $31 \mathrm{~d}$ of age. However, the interaction of age with diets was rarely significant, so mean dietary FA responses across ages are provided in Table 4. Among the changes in PUFA, concentrations of linoleic acid, C20:2n-6, C20:4n-6, $\mathrm{C} 22: 5 \mathrm{n}-3$, and $\mathrm{C} 22: 6 \mathrm{n}-3$ in plasma decreased $(P<$ 0.01 ), whereas concentrations of $\mathrm{C} 18: 3 \mathrm{n}-6, \alpha$-linolenic acid, C20:3n-6, and C22:4n-6 increased $(P \leq 0.05)$ in calves at 60 compared with $30 \mathrm{~d}$ of age (Table 4$)$. These small changes were likely due to dietary changes and to resulting development of ruminal bacteria responsible for biohydrogenation of dietary PUFA.

Interestingly, the source of FA fed prepartum had a long-term effect $(60 \mathrm{~d})$ on the circulating FA profile of calves born from those dams. Proportion of total SFA in plasma of calves born from dams fed the SFA supplement was greater (35.7 vs. $34.6 \% ; P=0.01)$ and that of linoleic acid tended to be less ( 42.5 vs. $44.0 \%$; 
or high linoleic acid (HLA) at 30 and $60 \mathrm{~d}$ of age ${ }^{1}$

\begin{tabular}{|c|c|c|c|c|c|c|c|c|c|c|c|c|c|c|c|c|}
\hline \multirow[b]{3}{*}{$\mathrm{FA}, \mathrm{mg} / \mathrm{mL}$} & \multicolumn{6}{|c|}{ Dam $\operatorname{diet}^{2}$ and milk replacer ${ }^{3}$} & \multirow[b]{3}{*}{ SEM } & & & & \multicolumn{6}{|c|}{$P$-value ${ }^{4}$} \\
\hline & \multicolumn{2}{|c|}{ Control } & \multicolumn{2}{|c|}{ SFA } & \multicolumn{2}{|c|}{ EFA } & & \multicolumn{2}{|c|}{ Age } & \multirow[b]{2}{*}{ SEM } & \multicolumn{2}{|c|}{ Dam diet } & \multirow[b]{2}{*}{ MR } & \multirow{2}{*}{$\begin{array}{c}\text { FAT } \times \\
\text { MR }\end{array}$} & \multirow{2}{*}{$\begin{array}{c}\text { FAS } \times \\
\text { MR }\end{array}$} & \multirow[b]{2}{*}{ Age } \\
\hline & LLA & HLA & LLA & HLA & LLA & HLA & & $30 \mathrm{~d}$ & $60 \mathrm{~d}$ & & FAT & FAS & & & & \\
\hline FA & 2.04 & 1.95 & 2.12 & 1.95 & 2.12 & 1.93 & 0.07 & 2.01 & 2.02 & 0.03 & 0.62 & 0.88 & 0.02 & 0.48 & 0.90 & 0.91 \\
\hline C10:0 & 0.03 & 0.00 & 0.06 & 0.01 & 0.02 & 0.03 & 0.02 & 0.02 & 0.03 & 0.01 & 0.36 & 0.32 & 0.06 & 0.61 & 0.06 & 0.34 \\
\hline C12:0 & 0.91 & 0.44 & 0.89 & 0.59 & 0.65 & 0.42 & 0.06 & 0.65 & 0.64 & 0.04 & 0.55 & $<0.01$ & $<0.01$ & 0.07 & 0.63 & 0.89 \\
\hline C14:0 & 4.73 & 2.22 & 4.89 & 2.58 & 4.70 & 2.17 & 0.16 & 3.19 & 3.46 & 0.10 & 0.42 & 0.05 & $<0.01$ & 0.60 & 0.21 & 0.04 \\
\hline cis-9 C14:1 & 0.18 & 0.24 & 0.25 & 0.22 & 0.24 & 0.20 & 0.02 & 0.16 & 0.28 & 0.01 & 0.43 & 0.62 & 0.81 & 0.04 & 0.90 & $<0.01$ \\
\hline C15:0 & 0.41 & 0.48 & 0.45 & 0.43 & 0.46 & 0.45 & 0.05 & 0.46 & 0.43 & 0.02 & 0.96 & 0.75 & 0.71 & 0.35 & 0.90 & 0.03 \\
\hline C16:0 & 16.0 & 16.6 & 16.2 & 16.7 & 16.4 & 16.2 & 0.27 & 16.8 & 16.0 & 0.15 & 0.73 & 0.63 & 0.21 & 0.41 & 0.17 & $<0.01$ \\
\hline cis-9 C16:1 & 1.21 & 1.34 & 1.11 & 1.40 & 1.09 & 1.35 & 0.06 & 1.24 & 1.25 & 0.03 & 0.46 & 0.58 & $<0.01$ & 0.18 & 0.82 & 0.68 \\
\hline C17:0 & 0.37 & 0.36 & 0.34 & 0.37 & 0.34 & 0.37 & 0.03 & 0.31 & 0.41 & 0.01 & 0.68 & 0.92 & 0.47 & 0.34 & 0.97 & $<0.01$ \\
\hline cis-9 C17:1 & 0.07 & 0.09 & 0.07 & 0.07 & 0.07 & 0.10 & 0.02 & 0.07 & 0.08 & 0.01 & 0.38 & 0.54 & 0.02 & 0.25 & 0.27 & 0.04 \\
\hline C18:0 & 13.8 & 13.3 & 13.9 & 13.9 & 13.7 & 13.2 & 0.25 & 13.2 & 14.1 & 0.13 & 0.47 & 0.11 & 0.10 & 0.71 & 0.38 & $<0.01$ \\
\hline cis-9 C18:1 & 10.9 & 10.0 & 11.6 & 10.5 & 11.3 & 9.9 & 0.42 & 10.7 & 10.6 & 0.21 & 0.31 & 0.27 & $<0.01$ & 0.77 & 0.71 & 0.87 \\
\hline C18:2n-6 & 41.6 & 46.8 & 39.9 & 45.1 & 41.1 & 47.0 & 0.89 & 44.3 & 42.8 & 0.44 & 0.23 & 0.09 & $<0.01$ & 0.79 & 0.75 & $<0.01$ \\
\hline C18:3n-6 & 0.34 & 0.22 & 0.37 & 0.19 & 0.32 & 0.17 & 0.03 & 0.21 & 0.32 & 0.01 & 0.45 & 0.20 & $<0.01$ & 0.43 & 0.52 & $<0.01$ \\
\hline C18:3n-3 & 0.70 & 0.86 & 0.65 & 0.77 & 0.68 & 0.81 & 0.05 & 0.68 & 0.80 & 0.03 & 0.23 & 0.50 & $<0.01$ & 0.74 & 0.84 & $<0.01$ \\
\hline C20:2n-6 & 0.19 & 0.25 & 0.21 & 0.25 & 0.21 & 0.29 & 0.03 & 0.26 & 0.21 & 0.01 & 0.41 & 0.28 & 0.01 & 0.97 & 0.46 & $<0.01$ \\
\hline C20:3n-6 & 1.34 & 0.90 & 1.38 & 0.98 & 1.32 & 0.98 & 0.06 & 1.08 & 1.22 & 0.04 & 0.39 & 0.59 & $<0.01$ & 0.48 & 0.68 & $<0.01$ \\
\hline C20:4n-6 & 3.21 & 2.82 & 3.14 & 3.03 & 3.17 & 3.17 & 0.11 & 3.31 & 2.87 & 0.06 & 0.23 & 0.45 & 0.05 & 0.07 & 0.58 & $<0.01$ \\
\hline C20:5n-3 & 0.12 & 0.08 & 0.13 & 0.07 & 0.12 & 0.07 & 0.02 & 0.11 & 0.09 & 0.01 & 0.88 & 0.74 & $<0.01$ & 0.74 & 0.83 & 0.11 \\
\hline C22:4n-6 & 0.22 & 0.23 & 0.24 & 0.22 & 0.25 & 0.25 & 0.03 & 0.22 & 0.25 & 0.01 & 0.41 & 0.33 & 0.84 & 0.81 & 0.74 & 0.05 \\
\hline C22:5n-3 & 0.29 & 0.33 & 0.30 & 0.30 & 0.28 & 0.36 & 0.02 & 0.33 & 0.28 & 0.01 & 0.78 & 0.24 & $<0.01$ & 0.76 & 0.01 & $<0.01$ \\
\hline C22:6n-3 & 0.26 & 0.20 & 0.25 & 0.23 & 0.19 & 0.22 & 0.02 & 0.29 & 0.16 & 0.01 & 0.85 & 0.10 & 0.43 & 0.10 & 0.20 & $<0.01$ \\
\hline Others $^{5}$ & 3.54 & 3.03 & 3.53 & 2.91 & 3.43 & 2.97 & 0.27 & 2.57 & 3.90 & 0.12 & 0.75 & 0.94 & 0.02 & 0.95 & 0.77 & $<0.01$ \\
\hline$\Sigma$ SFA & 36.3 & 33.4 & 36.8 & 34.6 & 36.4 & 32.9 & 0.44 & 34.8 & 35.2 & 0.23 & 0.42 & 0.01 & $<0.01$ & 0.94 & 0.14 & 0.19 \\
\hline$\Sigma$ MUFA & 11.9 & 10.8 & 13.1 & 11.3 & 12.5 & 10.8 & 0.41 & 11.7 & 11.7 & 0.21 & 0.11 & 0.20 & $<0.01$ & 0.30 & 0.95 & 0.89 \\
\hline$\Sigma$ PUFA n-6 & 47.0 & 51.2 & 45.2 & 49.8 & 46.4 & 51.8 & 0.88 & 49.4 & 47.7 & 0.43 & 0.32 & 0.07 & $<0.01$ & 0.61 & 0.63 & $<0.01$ \\
\hline$\Sigma$ PUFA n-3 & 1.37 & 1.47 & 1.33 & 1.37 & 1.26 & 1.47 & 0.06 & 1.42 & 1.33 & 0.03 & 0.26 & 0.80 & 0.02 & 0.86 & 0.17 & 0.04 \\
\hline
\end{tabular}

${ }^{1}$ Calves were born from dams fed diets supplemented with no fat (control), SFA, or essential FA (EFA) starting at 8 wk before expected calving date.

${ }^{2} \mathrm{SFA}=$ Energy Booster 100 (Milk Specialties Co., Dundee, IL); EFA = Megalac-R (Church \& Dwight Co. Inc., Princeton, NJ).

${ }^{3}$ Milk replacer was the only feed offered during the first $30 \mathrm{~d}$ of life. Daily intakes of linoleic acid from MR (after correcting for refusals) were 0.14 and $0.45 \mathrm{~g} / \mathrm{kg}$ of BW $\mathrm{W}^{0.75}$ for LLA and HLA MR, respectively.

${ }^{4} P$-values for orthogonal contrasts: FAT $=$ control versus SFA + EFA; FAS $=$ EFA versus SFA; MR $=$ LLA versus HLA.

${ }^{5}$ Unidentified FA. 
$P=0.09)$ compared with calves born from dams fed the EFA supplement (Table 4). This effect may be due to the deposition of FA by calves in utero that can be mobilized after birth.

The vast majority of liquid feeds are not exposed to microbial fermentation in the rumen due to the delivery of those feeds to the omasum-abomasum via the esophageal groove in calves. All of the FA consumed in the first $30 \mathrm{~d}$ and $89 \%$ of the FA consumed in the second $30 \mathrm{~d}$ originated in liquid feeds in the current study and therefore escaped ruminal metabolism. As a result, the FA profile of the plasma should reflect the FA profile of the MR. Concentrations of linoleic and $\alpha$-linolenic acids in plasma at birth did not differ in calves assigned to receive LLA or HLA MR (Garcia et al., 2014). However, by replacing a portion of the CCO in the LLA MR with porcine lard, the proportions of medium-chain FA in plasma were decreased $(P<0.01)$, namely $\mathrm{C} 12: 0$ from 0.82 to $0.48 \%$ and $\mathrm{C} 14: 0$ from 4.8 to $2.3 \%$ (Table 4). Fatty acids found in greater concentrations in porcine lard compared with $\mathrm{CCO}$ were increased in plasma of calves fed porcine lard; specifically, C16:1 (1.4 vs. $1.1 \% ; P<0.01)$, linoleic acid (46.3 vs. $40.9 \% ; P<0.01)$, and $\alpha$-linolenic acid (0.81 vs. $0.68 \% ; P<0.01)$. These results are in agreement with previous studies in which $\mathrm{CCO}$ or corn oil were fed in MR to dairy calves (Jenkins et al., 1985; Jenkins and Kramer, 1986).

The $\Delta^{6}$ - $(\mathrm{EC}=1.14 .19 .3)$ and $\Delta^{5}-(\mathrm{EC}=1.14 .19 .-)$ desaturase activities calculated by the desaturase indices of C18:3n-6, C20:4n-6, and C20:5n-3 (Loor and Herbein, 2003) were reduced $(P<0.01$; data not shown, $)$ in calves fed HLA compared with calves fed LLA MR. The reduced activity of desaturases resulted in plasma of calves fed HLA MR having greater proportions of linoleic acid (46.3 vs. $40.9 \% ; P<0.01$ ) and $\alpha$-linolenic acid ( 0.81 vs. $68 \% ; P<0.01)$ but reduced proportions of FA derivatives of linoleic acid (Table 4), namely C18:3n-6 (0.19 vs. $0.35 ; P<0.01)$, C20:3n-6 (0.95 vs. $1.35 \% ; P<0.01$ ), and $\mathrm{C} 20: 4 n-6$ (3.00 vs. $3.17 \% ; P$ $=0.05)$, and reduced proportion of the FA derivative of $\alpha$-linolenic acid, namely C20:5n-3 (0.07 vs. $0.12 \%$; $P<0.01)$. In agreement, Cho et al. (1999) reported decreased gene expression and activity of $\Delta^{6}$-desaturase in the livers of mice fed corn oil compared with those fed triolein. The desaturase indices for $\mathrm{C} 22: 5 \mathrm{n}-3$ and C22:6n-3 did not differ due to MR and concentrations were increased (C22:5n-3; $P<0.01)$ or unchanged $(\mathrm{C} 22: 6 \mathrm{n}-3 ; P=0.43)$ by the increased intake of linoleic acid from the MR (Table 4). The fact that linoleic acid can compete with $\alpha$-linolenic acid for enzymes required to convert these parent FA to longer-chain derivatives (Gibson et al., 2011) may help explain the decreased concentrations of C20:5n-3 in plasma of calves fed HLA
MR; however, linoleic acid was totally nonrepressive on C22:5n-3 and C22:6n-3. The FA C22:6n-3 (and its precursor C22:5n-3) is critical for the development of the central nervous system (Bradbury, 2011). Based on kinetic and enzymatic data for activity of $\Delta^{5}$ - and $\Delta^{6}$ desaturases and elongases 2 and 5 in liver, Igarashi et al. (2007) concluded that the liver of rats could synthesize the amount of C22:6n-3 needed by the brain even when fed diets deficient in $\alpha$-linolenic acid. Neonatal calves may synthesize $\mathrm{C} 22: 5 \mathrm{n}-3$ and $\mathrm{C} 22: 6 \mathrm{n}-3$ to meet the needs of the brain and nervous tissue, regardless of the enzymatic competition between n- 6 and n-3 FA.

At $30 \mathrm{~d}$ of age, the liver of male calves $(\mathrm{n}=31)$ was biopsied and analyzed for FA. The ratio of C20:3n-9 to C20:4n-6 in total hepatic tissue was greater for calves fed LLA compared with those fed HLA MR (0.01 vs. $0.02 ; P<0.01)$ but both ratios were far below the ratio $(>0.2)$ used to describe linoleic acid deficiency (Holman, 1978). In addition, this ratio was less for calves born from dams fed the EFA supplement than for calves born from dams fed the SFA supplement (0.01 vs. $0.02 ; P<0.01)$.

\section{Measures of Growth and Feed Efficiency}

Concentrations of $\operatorname{IgG}$ in serum within 24 to $30 \mathrm{~h}$ after feeding colostrum were not affected by diets and averaged $2.53 \mathrm{~g} / \mathrm{dL}$ (Table 5), more than twice the recommended values of $1 \mathrm{~g}$ of $\mathrm{IgG} / \mathrm{dL}$ to ensure an appropriate passive transfer (Tyler et al., 1996). However, 1 calf born from a dam fed the SFA supplement and assigned to HLA MR failed to reach the recommended amount of IgG. Mean birth weights were 40.2, 41.5, and $41.0 \mathrm{~kg}$ for calves born from dams fed control, SFA, and EFA diets, respectively and were not affected by prepartum diet (Table 5). Similarly, feeding supplements differing in FA profile but providing similar amounts of energy to prepartum grazing cross-bred beef cows did not influence birth weights of calves (Banta et al., 2011).

Calves of both sexes born from cattle fed the SFA supplement prepartum had greater ADG over the $60-\mathrm{d}$ period $(P=0.04)$ compared with calves born from cattle fed the EFA supplement prepartum (0.50 vs. $0.46 \mathrm{~kg} / \mathrm{d}$; Table 5). This greater gain was due to a tendency $(P=0.07)$ for calves to consume more DM (48.8 vs. $45.6 \mathrm{~kg}$ ), specifically due to greater intake of grain mix during the last $30 \mathrm{~d}$ of the study (13.1 vs. $10.9 \mathrm{~kg}$ of $\mathrm{DM} ; P=0.06)$. The increased gain by calves born from dams fed the SFA supplement was explained by increased DMI when DMI was used as a covariate in the reanalysis of BW gain.

Calves fed the HLA MR had consistently greater ADG compared with calves fed the LLA MR [an in- 
Table 5. Serum IgG, BW, intake, ADG, and feed efficiency of Holstein calves fed milk replacers (MR) containing low linoleic acid (LLA) or high linoleic acid (HLA) from 1 to 60 d of age a $^{1}$

\begin{tabular}{|c|c|c|c|c|c|c|c|c|c|c|c|c|}
\hline \multirow[b]{3}{*}{ Measure } & \multicolumn{6}{|c|}{ Dam diet ${ }^{2}$ and milk replacer ${ }^{3}$} & \multirow[b]{3}{*}{ SEM } & \multicolumn{5}{|c|}{$P$-value ${ }^{4}$} \\
\hline & \multicolumn{2}{|c|}{ Control } & \multicolumn{2}{|c|}{ SFA } & \multicolumn{2}{|c|}{ EFA } & & \multicolumn{2}{|c|}{ Dam diet } & \multirow[b]{2}{*}{ MR } & \multirow{2}{*}{$\begin{array}{c}\text { FAT } \\
\times \mathrm{MR}\end{array}$} & \multirow{2}{*}{$\begin{array}{r}\text { FAS } \\
\times \mathrm{MR}\end{array}$} \\
\hline & LLA & HLA & LLA & HLA & LLA & HLA & & FAT & FAS & & & \\
\hline $\begin{array}{l}\text { Serum } \operatorname{IgG},{ }^{5} \mathrm{~g} / \mathrm{dL} \\
\text { Birth to } 30 \mathrm{~d} \text { of age }\end{array}$ & 2.23 & 2.59 & 2.49 & 2.95 & 2.53 & 2.39 & 0.20 & 0.31 & 0.20 & 0.16 & 0.57 & 0.13 \\
\hline Birth weight, $\mathrm{kg}$ & 38.7 & 41.6 & 40.6 & 42.4 & 41.7 & 40.3 & 1.3 & 0.32 & 0.71 & 0.30 & 0.23 & 0.23 \\
\hline MR intake, $\mathrm{kg}$ of $\mathrm{DM}$ & 14.7 & 15.6 & 15.3 & 16.0 & 15.3 & 15.2 & 0.4 & 0.43 & 0.35 & 0.15 & 0.41 & 0.35 \\
\hline $\mathrm{ADG}, \mathrm{kg} / \mathrm{d}$ & 0.25 & 0.31 & 0.27 & 0.34 & 0.27 & 0.28 & 0.02 & 0.76 & 0.19 & 0.02 & 0.60 & 0.23 \\
\hline Feed efficiency ${ }^{6}$ & 0.51 & 0.60 & 0.53 & 0.63 & 0.52 & 0.56 & 0.05 & 0.99 & 0.34 & 0.05 & 0.87 & 0.54 \\
\hline \multicolumn{13}{|l|}{$31 \mathrm{~d}$ of age to weaning } \\
\hline MR intake, $\mathrm{kg}$ of DM & 18.8 & 20.1 & 19.5 & 20.6 & 19.4 & 19.6 & 0.5 & 0.50 & 0.28 & 0.03 & 0.42 & 0.30 \\
\hline GM intake, ${ }^{7} \mathrm{~kg}$ of DM & 10.4 & 11.9 & 13.8 & 12.5 & 11.3 & 10.6 & 1.1 & 0.36 & 0.06 & 0.81 & 0.22 & 0.79 \\
\hline $\mathrm{ADG}, \mathrm{kg} / \mathrm{d}$ & 0.63 & 0.68 & 0.68 & 0.71 & 0.59 & 0.68 & 0.03 & 0.69 & 0.11 & 0.05 & 0.81 & 0.44 \\
\hline Feed efficiency & 0.65 & 0.64 & 0.62 & 0.64 & 0.58 & 0.68 & 0.03 & 0.66 & 0.93 & 0.09 & 0.13 & 0.19 \\
\hline \multicolumn{13}{|l|}{ Birth to weaning } \\
\hline Final BW, kg & 65.3 & 71.7 & 69.0 & 74.1 & 67.6 & 69.3 & 2.0 & 0.36 & 0.12 & 0.01 & 0.40 & 0.39 \\
\hline Total DMI, kg & 44.0 & 47.7 & 48.6 & 49.0 & 46.0 & 45.3 & 1.7 & 0.32 & 0.07 & 0.39 & 0.18 & 0.73 \\
\hline $\mathrm{ADG}, \mathrm{kg} / \mathrm{d}$ & 0.44 & 0.49 & 0.47 & 0.53 & 0.43 & 0.48 & 0.02 & 0.49 & 0.04 & $<0.01$ & 0.94 & 0.92 \\
\hline Feed efficiency & 0.60 & 0.62 & 0.59 & 0.64 & 0.57 & 0.64 & 0.03 & 0.93 & 0.63 & 0.01 & 0.23 & 0.61 \\
\hline
\end{tabular}

${ }^{1}$ Calves were born from cows fed diets supplemented with no fat (control), SFA, or essential FA (EFA) starting at 8 wk before expected calving date. Effect of sex and interactions were not significant.

${ }^{2}$ SFA = Energy Booster 100 (Milk Specialties Co., Dundee, IL); EFA = Megalac-R (Church \& Dwight Co. Inc., Princeton, NJ).

${ }^{3}$ Milk replacer was the only feed offered during the first $30 \mathrm{~d}$ of life. Daily intakes of linoleic acid from MR (after correcting for refusals) were 0.14 and $0.45 \mathrm{~g} / \mathrm{kg}$ of BW $\mathrm{W}^{0.75}$ for LLA and HLA MR, respectively.

${ }^{4} P$-values for orthogonal contrasts: FAT $=$ control versus SFA + EFA; FAS $=$ EFA versus SFA; MR $=$ LLA versus HLA

${ }^{5}$ Serum IgG after 24 to $30 \mathrm{~h}$ of colostrum feeding.

${ }^{6}$ Feed efficiency is kilograms of BW gain per kilogram of DMI.

${ }^{7}$ Grain mix (GM) was fed exclusively the last $30 \mathrm{~d}$ of the preweaning period. 
crease of 18,9 , and $15 \%$ for the first $30 \mathrm{~d}(P=0.02)$, the second $30 \mathrm{~d}(P=0.05)$, and the whole 60 -d period $(P<0.01)$, respectively], regardless of the dam diet (Table 5). Total intake of grain mix (mean of $11.7 \mathrm{~kg}$ of DM across diets) during the last $30 \mathrm{~d}$ of the study was not affected by type of MR fed. Intake of MR did not differ the first $30 \mathrm{~d}$ but was greater $(P=0.03)$ for calves fed the HLA MR during the 31- to 60-d period because the heavier calves in the HLA group would have been offered more MR per the design of the feeding regimen. However, total DMI (MR and grain mix) was not different between MR groups from 31 to $60 \mathrm{~d}$ of age. Therefore, total DMI between MR groups over the 60-d study was not different. This improved gain without changing total DMI resulted in improved feed efficiency (FE; $\mathrm{kg}$ of BW gain/ $\mathrm{kg}$ of DMI) of calves fed HLA compared with those fed LLA during the first 30 d (0.60 vs. $0.52 ; P=0.05)$, during 31 to $60 \mathrm{~d}$ ( 0.65 vs. $0.62 ; P=0.09$ ), and during 1 to $60 \mathrm{~d}$ (0.63 vs. $0.59 ; P$ $=0.01)$. The improved ADG and FE apparently were due to the superiority of the HLA MR formulation (i.e., greater intake of linoleic acid) rather than to greater intake of the grain mix. Jenkins et al. (1985) did not report differences in ADG and FE in calves fed CCO or tallow, possibly because both MR had similar concentrations of linoleic acid (3.2 to $3.8 \%$ of FA). Huuskonen et al. (2005) reported no difference in BW gain but reduced FE by Ayrshire bull calves fed MR formulated with lard (12\% linoleic acid of total FA) compared with vegetable oils including $\mathrm{CCO}$ (7 to $8 \%$ linoleic acid of total FA). Calves also were offered grain and silage in the preweaning period. In beef cattle, supplementing high linoleate versus high oleate cracked safflower seeds (approximately 69 vs. $11 \%$ of dietary FA as linoleic acid) to lactating beef cows did not influence BW gain of suckling calves (Lake et al., 2005). Intake of linoleic acid from the control diets in the aforementioned studies may have been sufficient so that additional intake of linoleic acid did not improve calf performance.

\section{Metabolic and Hormonal Profiles}

Calves born from dams fed the SFA supplement had greater ADG from birth to weaning compared with those born from dams fed the EFA supplement, primarily due to greater intake of grain (Table 5) yet their plasma metabolic profiles for glucose, BHBA, NEFA, cholesterol, insulin, and IGF-1 were not different $(P$ $>0.10$; Table 6 ). Similarly, adding grain to the diet of calves fed MR and hay did not affect concentrations of these same variables (Laarman et al., 2012) and ADG was unchanged as well. Conversely, the mean concentration and pattern of several plasma metabolites were different between calves fed LLA and those fed HLA
MR. These differences likely were due to differences in ADG and MR composition. Concentrations of glucose in blood plasma were greatest at $1 \mathrm{~d}$ of age, exceeding $100 \mathrm{mg} / \mathrm{dL}$, but decreased to between 85 and $95 \mathrm{mg} /$ $\mathrm{dL}$ for the remainder of the study (effect of age: $P<$ 0.01 ). Mean concentration of glucose was $2.8 \mathrm{mg} / 100$ $\mathrm{mL}$ greater in plasma of calves fed HLA compared with calves fed LLA MR (92.7 vs. $89.9 \mathrm{mg} / \mathrm{dL} ; P=0.03$; Table 6). This effect held throughout the 60-d study, as MR by age interaction was not significant. Mean concentrations of glucose in plasma were greater in dairy bull calves gaining more BW but they also consumed more DM (Foote et al., 2007; Ballou, 2012).

Concentrations of insulin in plasma were lowest at birth (mean of $0.91 \mathrm{ng} / \mathrm{mL}$ ) but increased by approximately $65 \%$ at $24 \mathrm{~h}$ after colostrum consumption (1.49 $\mathrm{ng} / \mathrm{mL}$ ). Thereafter, concentrations were steady until increasing again after initiation of feeding grain (effect of age: $P<0.01$ ). Neither dam diet nor MR affected mean concentration of insulin, although means were numerically greater for calves fed HLA compared with LLA MR (1.44 vs. $1.28 \mathrm{ng} / \mathrm{mL} ; P=0.14)$. Concentrations of IGF-1 in plasma were greatest at birth $(85 \mathrm{ng} /$ $\mathrm{mL}$ ), decreased by two-thirds by $14 \mathrm{~d}$ of age ( $28 \mathrm{ng} /$ $\mathrm{mL})$, and returned to birth values by 8 wk of age $(77$ $\mathrm{ng} / \mathrm{mL}$; effect of age: $P<0.01)$. Similar to the pattern of insulin in plasma, calves fed HLA MR tended $(P$ $=0.08)$ to have greater mean concentration of IGF-1 compared with those fed LLA MR (59.7 vs. $53.2 \mathrm{ng} /$ $\mathrm{mL}$; Table 6). Dairy calves fed more MR (Smith et al., 2002) or more fat and protein (Quigley et al., 2006; Daniels et al., 2008; Hill et al., 2008), with resulting enhanced ADG, had increased plasma concentrations of glucose, insulin, and or IGF-1, thus demonstrating the effect on nutrient intake on these plasma constituents. In the current study, no difference in DMI over the 60-d period was detected between calves fed LLA and HLA MR (Table 5). However, increased intake of linoleic acid may have been responsible for improved gain of calves fed HLA MR. Hypertrophy through increased protein synthesis as well as through proliferation and fusion of myosatellite cells is the most common mechanism for postnatal skeletal muscle growth (Schiaffino et al., 2013). However, Allen et al. (1985) reported that addition of linoleic acid to culture medium markedly improved fusion of satellite cells without a significant increase in cell number. They hypothesized that the effect of linoleic acid might be due to the provision of an "essential element" required for cell membrane changes as associated with myoblast fusion. Fatty acids are not only structural components of the phospholipid cell membrane whose proportions can be modified, but also they can affect membrane fluidity, formation of lipid rafts, intracellular signaling processes, gene expression, 
and the production of both lipid and peptide mediators (Calder, 2012).

Intake of lactose was not different between MR over the 60-d experimental period, so the supply of glucose was similar. Circulating IGF-I is derived from hepatic synthesis through the action of growth hormone (GH; Le Roith et al., 2001). Smith et al. (2002) reported that the GH:IGF-I axis is functional and sensitive to nutrient intake in preweaned calves. Although GH was not measured in the current study, circulating concentrations likely were increased in calves fed HLA MR and may have influenced peripheral tissues directly to stimulate cell growth without mediation of IGF-I and by stimulation of IGF-I synthesis, which carries out autocrine and paracrine functions to enhance cell growth (Le Roith et al., 2001).

Concentrations of PUN were steady through the period of feeding MR alone (mean of $8.9 \mathrm{mg} / \mathrm{dL}$ ) and progressively decreased thereafter to a mean of $5.8 \mathrm{mg} /$ dL by 8 wk of age. Mean concentration of PUN tended to be reduced in calves fed HLA compared with those fed LLA (7.7 vs. $8.3 \mathrm{mg} / 100 \mathrm{~mL} ; P=0.06$; Table 6 ). Reduced PUN concentration may be due to increased circulating concentrations of IGF-1, as increased protein synthesis and reduced protein oxidation have been associated with IGF-1 administration in humans (Le Roith et al., 2001). These effects would likely improve the efficiency of protein deposition, leading to improved gain in BW. Unexpectedly, feeding fat prepartum increased the mean concentration of PUN in plasma of calves ( 8.3 vs. $7.6 \mathrm{mg} / 100 \mathrm{~mL} ; P=0.05)$ over the first $60 \mathrm{~d}$ of life. This may reflect an epigenetic effect of dam diet (e.g., fat supplementation) on calf metabolism of dietary protein and should be studied further.

Concentrations of BHBA in plasma peaked during the second week of life, gradually decreased until approximately $30 \mathrm{~d}$ of age, and then gradually increased once grain intake began (effect of age: $P<0.01$; Figure 1). Mean concentration of BHBA in plasma of calves born from cattle fed fat tended to be greater compared with that of calves born from dams fed the control diet (1.21 vs. $0.94 \mathrm{mg} / 100 \mathrm{~mL} ; P=0.06$; Table 6). Mean concentrations of BHBA in plasma were consistently lower in calves fed HLA compared with those fed LLA MR (1.36 vs. $0.87 \mathrm{mg} / 100 \mathrm{~mL} ; P<0.01$; Table 6 and Figure 1). Mean concentrations of NEFA in plasma were greatest in the first week of life $(\sim 312 \mu \mathrm{Eq} / \mathrm{L})$ and gradually decreased for 4 wk before plateauing at less than half of initial values thereafter (effect of age: $P<$ 0.01). Neither prepartum nor preweaning diets affected mean concentrations of NEFA in plasma (mean of 170 $\mu \mathrm{Eq} / \mathrm{L})$.

Concentrations of total cholesterol in plasma rose from approximately $25 \mathrm{mg} / 100 \mathrm{~mL}$ at birth to $\geq 120 \mathrm{mg} / 100$ 


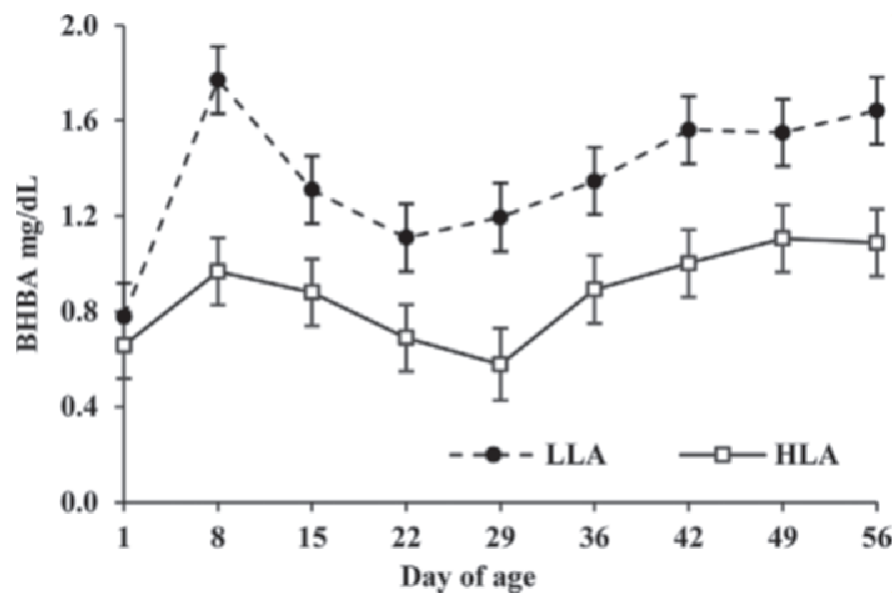

Figure 1. Plasma concentrations of BHBA in Holstein calves fed milk replacer containing low linoleic acid (LLA) or high linoleic acid (HLA) from 1 to $60 \mathrm{~d}$ of age. Calves were born from cows fed diets supplemented with no fat (control), SFA, or essential FA starting at 8 wk before expected calving date. Grain was offered starting at $31 \mathrm{~d}$ of life. Effect of milk replacer: $P<0.01$; effect of age: $P<0.01$.

$\mathrm{mL}$ by $60 \mathrm{~d}$ of age (effect of age: $P<0.01$; Figure 2 ). Calves fed HLA MR had lower concentrations of total cholesterol in plasma starting at $19 \mathrm{~d}$ of age compared with those fed LLA MR $(\mathrm{MR} \times$ age interaction: $P=$ 0.01). However, the type of dam diet tended to interact with MR to affect mean concentrations of cholesterol in plasma. Feeding PUFA (safflower oil) to weaned mice resulted in decreased concentrations of cholesterol in plasma only if their dams were fed PUFA rather than less unsaturated FA (lard; Chechi and Cheema, 2006). Modification of hepatic liver metabolism through fetal programming warrants further investigation.

Cholesterol and BHBA are synthesized primarily in the liver of preruminant calves as products of lipid metabolism (Drackley, 2005). Considering that the production of BHBA by the ruminal epithelium is low due to minimal microbial activity in calves fed only MR, the increased concentrations of BHBA in plasma likely was due to incomplete oxidation of FA in the liver. Sato (1994) fed medium-chain FA (C8 and C10) to neonatal calves, causing marked hyperketonemia within a few hours after feeding due to preferential transport of these FA through the portal vein and greater availability of FA for oxidation and synthesis of ketogenic products. These same biological processes likely were occurring in calves fed the LLA MR rich in mediumchain FA coming from CCO. Medium-chain SFA such as C12:0, C14:0, and C16:0 have been identified as the most potent inducers of cholesterolemia in laboratory animals (Fernandez and West, 2005), whereas PPAR- $\alpha$, once activated by linoleic acid, enhances the activity of enzymes responsible for increasing clearance of cholesterol (Li and Chiang, 2009).

\section{Incidence of Diarrhea and Poor Attitude}

Feeding HLA rather than LLA MR during the first $30 \mathrm{~d}$ of life increased the percentage of days that calves scored a poor attitude (score $>1$ ) if calves were born from dams fed the control diet (12.3 vs. $5.3 \%$ ), whereas type of MR had no effect on days with poor attitude if calves were born from dams fed fat prepartum (5.8 vs. 8.0\%; $\mathrm{SEM}=2.0 \%$; FAT $\times$ MR interaction: $P=0.01$ ) During the first $30 \mathrm{~d}$ of life, the percentage of days with diarrhea (score $>2$ ) was reduced if calves were born from dams fed fat and were fed the HLA compared with those fed LLA MR (9.2 vs. 15.4\%), whereas diarrhea days were increased by feeding HLA instead of LLA MR if calves were born from dams fed the control $\operatorname{diet}(8.9$ vs. $17.7 \%$; SEM $=2.2 \%$; FAT $\times$ MR interaction: $P<0.01)$. The mechanisms driving these effects are not clear.

\section{Hematocrit, Serum Total Protein, and Blood Cell Populations}

Calves fed HLA MR tended to have a greater mean hematocrit ( 35.9 vs. $34.4 \%$; $P=0.08$; Table 7 ). This increase was consistent across days of age and was, therefore, not due to greater incidence of diarrhea, specific days of which occurred almost exclusively during wk 2 of life. Calves fed HLA MR grew faster and utilized nutrients more efficiently (Table 5). Faster-growing tissues would require more oxygen, which could be supplied by the organism via increased blood flow, increased oxygen saturation of the erythrocytes, and (or)

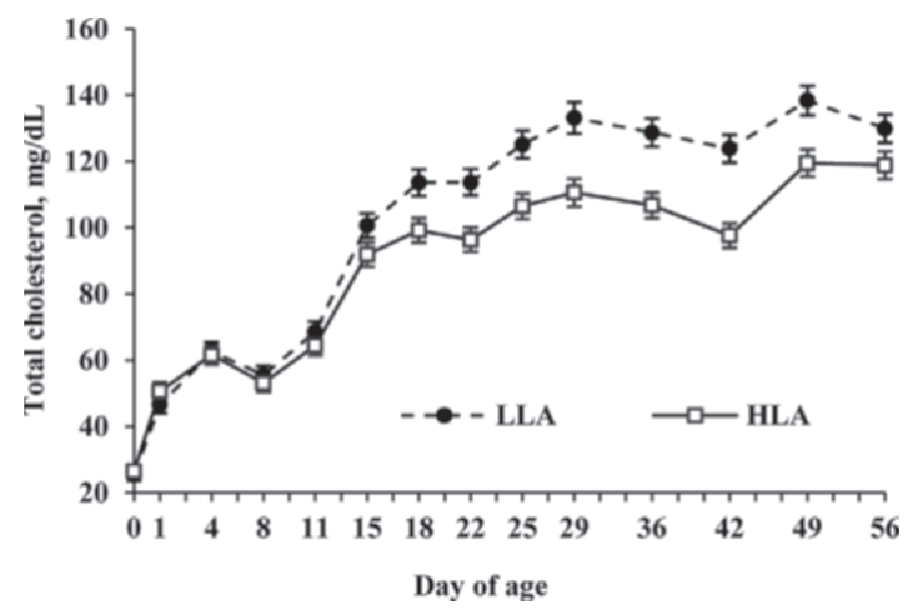

Figure 2. Plasma concentrations of total cholesterol in Holstein calves fed milk replacer containing low linoleic acid (LLA) or high linoleic acid (HLA) from 1 to $60 \mathrm{~d}$ of age. Calves were born from cows fed diets supplemented with no fat (control), SFA, or essential FA starting at $8 \mathrm{wk}$ before expected calving date. Grain was offered starting at $31 \mathrm{~d}$ of life. Effect of milk replacer by age interaction: $P=0.01$; slice effect from d 18 to $49: P \leq 0.01$. 
increased number of circulating erythrocytes. Increased hematocrit would support the latter mechanism. Mean concentration of STP at $1 \mathrm{~d}$ of age averaged $6.3 \mathrm{~g} /$ $\mathrm{dL}$, indicating that sufficient IgG in colostrum was fed. Mean STP concentrations across age were not affected by dam or calf diets (Table 7 ).

Mean blood concentrations of leukocytes (mean of $8.7 \times 10^{3} / \mu \mathrm{L}$ ) and neutrophils (mean of $3.1 \times 10^{3} / \mu \mathrm{L}$ ) were not affected by diets (Table 7 ). Mean blood concentrations of leukocytes were unchanged (Nonnecke et al., 2003) or increased (Ballou, 2012) in dairy calves consuming more DM and gaining more BW. Blood concentrations of lymphocytes increased with increasing age $(P<0.01)$ as reported previously (Kampen et al., 2006). Mean concentration of blood lymphocytes was greater in calves fed HLA compared with those fed LLA MR (4.61 vs. $\left.4.21 \times 10^{3} / \mu \mathrm{L} ; P=0.05\right)$, with the difference consistent throughout the study (Figure 3 ). The subpopulations of lymphocytes were not determined but the increase of these cells could reflect an improved immune response of calves fed HLA MR that might lead to improved growth. A highly activated immune system will require the body to partition more nutrients toward the support of resisting disease, leaving fewer nutrients in support of growth and performance (Colditz, 2002). A slower growth rate may result. However, if the immune system is not stimulated adequately, then incidence and duration of disease increases, resulting in reduced animal performance, even death. The organism must strike a balance between sufficient self-defense and over- or underreaction to pathogenic challenges. Because calves fed HLA MR had greater blood concentrations of circulating lymphocytes compared with those fed LLA MR, they may have had more immune agents available to deal quickly and effectively with the first signs of pathogens and tissue damage, representing a highly effective immune system.

\section{Adhesion Molecules, Phagocytic Activity of Neutrophils, and Blood Platelets}

Proper expression of CD62L and CD18 cell-adhesion molecules on the neutrophil surface allows suitable rolling and tethering of neutrophils on the endothelium to enhance their migration to the point of injury or infection (Simon et al., 2000). These molecules are expressed constitutively on the neutrophil surface but the number of these molecules expressed per neutrophil (GMFI) can be up- or downregulated as influenced by the animal's physiological status and dietary management. In the current study, neither the mean proportion of blood neutrophils expressing CD62L or CD18 (98.2 and $94.5 \%$ across diets, respectively) nor the mean GMFI of CD62L and CD18 (358 and 50 across diets, respectively) were affected by dietary treatments. However, other studies have reported effects of linoleic acid on these adhesion molecules. Rats consuming normal rat chow in ad libitum amounts were given by gavage $0.22 \mathrm{~g}$ of $\mathrm{C} 18: 1 \mathrm{n}-9$ or linoleic acid/ $\mathrm{kg}$ of BW for $10 \mathrm{~d}$. Daily intake of linoleic acid was increased about $10 \%$ via gavage (Rodrigues et al., 2010). In that study, migration of neutrophils into the peritoneum and expression of CD62L (GMFI) without a change in expression of CD18 (GMFI) was increased. Silvestre et al. (2011) reported an increase in percentage of blood neutrophils positive to CD62L and CD18 in dairy cows (4 and 7 DIM) fed Ca salts of safflower oil compared with those fed Ca salts of palm oil, whereas GMFI of CD62L but not that of CD18 was increased. Based on these studies, linoleic acid appears to be more proinflammatory than C18:1n-9 and C16:0; however, the basal innate immune defense and the amount of intake of linoleic acid that can stimulate these immune cells further in preweaned calves may differ appreciably from the mature cow and warrants further investigation.

Neutrophil function is incomplete if neutrophils that migrate to the infection zone are not able to phagocytize pathogens efficiently. Consequently, an enhanced ability to phagocytize pathogens potentially would result in increased effectiveness to minimize the negative effects of pathogens. The great majority of neutrophils did phagocytize bacteria in this trial (mean of $98 \%$; Table 7 ), possibly due to the extended incubation time $(2 \mathrm{~h})$ of blood neutrophils with bacteria. Dietary treatments did not influence the proportion or the circulating concentration of neutrophils carrying out phagocytosis (mean of $3.1 \times 10^{3} / \mu \mathrm{L}$ ). Efficiency of bacterial phagocytosis per neutrophil (GMFI) was not affected by the type of MR fed, but neutrophils from calves born from dams fed the SFA supplement were less efficient at phagocytosis (fewer bacteria per neutrophil, lower GMFI) compared with those of calves born from dams fed the EFA supplement (effect of FAS: 113 vs. $122 ; P=0.04$ ). Culturing murine macrophages from the peritoneal cavity with linoleic acid increased their phagocytic rate, whereas C16:0 decreased it compared with those not cultured with FA (Calder et al., 1990). Phagocytosis expressed as GMFI by neutrophils collected from healthy human adult subjects was correlated positively with the PBMC content of $\mathrm{C} 18: 0$ and linoleic acid but negatively with the PBMC content of C16:0 (Kew et al., 2003). The current results support the idea that C16:0 can reduce neutrophil activity even if fed prepartum. Some reasons for the lack of agreement of these studies may include differing intakes of linoleic acid, differing incubation times of neutrophils with $E$. coli, different chemicals used to stimulate PBMC, dif- 
Table 7. Blood concentrations of hematocrit, serum total protein (STP), blood leukocytes, platelets, expression of adhesion molecules on neutrophil surface, and phagocytic activity of neutrophils of Holstein calves fed a milk replacer (MR) containing low linoleic acid (LLA) or high linoleic acid (HLA) from 1 to $60 \mathrm{~d}$ of age

\begin{tabular}{|c|c|c|c|c|c|c|c|c|c|c|c|c|}
\hline \multirow[b]{3}{*}{ Measure $^{2}$} & \multicolumn{6}{|c|}{ Dam $\operatorname{diet}^{3}$ and milk replacer ${ }^{4}$} & \multirow[b]{3}{*}{ SEM } & \multicolumn{5}{|c|}{$P$-value ${ }^{5}$} \\
\hline & \multicolumn{2}{|c|}{ Control } & \multicolumn{2}{|c|}{ SFA } & \multicolumn{2}{|c|}{ EFA } & & \multicolumn{2}{|c|}{ Dam diet } & \multirow[b]{2}{*}{ MR } & \multirow{2}{*}{$\begin{array}{c}\text { FAT } \\
\times \text { MR }\end{array}$} & \multirow{2}{*}{$\begin{array}{r}\text { FAS } \\
\times \mathrm{MP}\end{array}$} \\
\hline & LLA & HLA & LLA & HLA & LLA & HLA & & FAT & FAS & & & \\
\hline Hematocrit, \% & 34.9 & 35.8 & 33.8 & 35.5 & 34.6 & 36.7 & 0.97 & 0.72 & 0.39 & 0.08 & 0.63 & 0.97 \\
\hline STP, $g / d L$ & 5.75 & 5.88 & 5.76 & 5.87 & 5.80 & 5.75 & 0.08 & 0.76 & 0.66 & 0.37 & 0.47 & 0.35 \\
\hline Leukocytes, $10^{3} / \mu \mathrm{L}$ & 8.46 & 8.75 & 8.60 & 9.35 & 8.23 & 8.58 & 0.49 & 0.85 & 0.26 & 0.25 & 0.76 & 0.72 \\
\hline Neutrophils, $10^{3} / \mu \mathrm{L}$ & $\begin{array}{l}0.40 \\
3.08\end{array}$ & $\begin{array}{l}0.10 \\
3.06\end{array}$ & $\begin{array}{l}0.00 \\
3.06\end{array}$ & $\begin{array}{l}\text { 9.50 } \\
3.58\end{array}$ & $\begin{array}{l}0.20 \\
2.95\end{array}$ & $\begin{array}{l}0.00 \\
2.87\end{array}$ & 0.27 & 0.88 & $\begin{array}{l}0.20 \\
0.14\end{array}$ & 0.56 & 0.62 & 0.29 \\
\hline Lymphocytes, $10^{3} / \mu \mathrm{L}$ & 4.26 & 4.57 & 4.29 & 4.57 & 4.08 & 4.68 & 0.24 & 0.96 & 0.79 & 0.05 & 0.74 & 0.50 \\
\hline Platelets, $10^{3} / \mu \mathrm{L}$ & 802 & 731 & 855 & 719 & 810 & 758 & 43.1 & 0.61 & 0.95 & 0.02 & 0.75 & 0.34 \\
\hline \multicolumn{13}{|l|}{ CD18 expression } \\
\hline$\%$ of neutrophils & 94.7 & 94.3 & 93.7 & 94.3 & 94.9 & 94.7 & 0.71 & 0.87 & 0.26 & 0.97 & 0.64 & 0.59 \\
\hline GMFI & 52 & 50 & 47 & 47 & 50.0 & 51 & 5.2 & 0.59 & 0.57 & 0.92 & 0.76 & 0.94 \\
\hline \multicolumn{13}{|l|}{ CD62L expression } \\
\hline$\%$ of neutrophils & 98.2 & 98.3 & 97.8 & 98.2 & 98.2 & 98.3 & 0.20 & 0.52 & 0.20 & 0.26 & 0.53 & 0.45 \\
\hline GMFI & 376 & 389 & 329 & 302 & 354 & 363 & 32.5 & 0.11 & 0.17 & 0.90 & 0.53 & 0.88 \\
\hline \multicolumn{13}{|l|}{ Phagocytic activity } \\
\hline Phagocytosis, \% & 95.6 & 96.2 & 95.8 & 96.5 & 95.2 & 96.0 & 0.55 & 0.94 & 0.33 & 0.14 & 0.95 & 0.93 \\
\hline Phagocytic neutrophils, $10^{3} / \mu \mathrm{L}$ & 3.05 & 3.16 & 3.10 & 3.74 & 2.98 & 2.88 & 0.29 & 0.83 & 0.10 & 0.39 & 0.79 & 0.22 \\
\hline GMFI & 119 & 121 & 112 & 114 & 121 & 122 & 4.2 & 0.52 & 0.04 & 0.59 & 0.98 & 0.99 \\
\hline
\end{tabular}

${ }^{1}$ Calves were born from cows fed diets supplemented with no fat (control), SFA, or essential FA (EFA) starting at 8 wk before expected calving date.

${ }^{2}$ Blood cells were measured 7 times and neutrophil function was measured 6 times during a 60 -d period. STP = serum total protein; GMFI $=$ geometric mean fluorescence intensity; ᄃ $\quad$ CD18 = mouse anti-canine $\beta_{2}$ integrin (IgG1 isotype; AbD Serotec, Raleigh, NC); CD62L = monoclonal mouse anti-bovine L-selectin (IgG1 isotype; AbD Serotec).

$\stackrel{{ }_{0}}{3} \mathrm{SFA}=$ Energy Booster 100 (Milk Specialties Co., Dundee, IL); EFA = Megalac-R (Church \& Dwight Co. Inc., Princeton, NJ).

吾 Milk replacer was the only feed offered during the first $30 \mathrm{~d}$ of life. Daily intakes of linoleic acid from MR (after correcting for refusals) were 0.14 and $0.45 \mathrm{~g} / \mathrm{kg}$ of BW ${ }^{0.75}$ for LLA $\stackrel{0}{\circ}$ and HLA MR, respectively.

${ }^{5} P$-values for orthogonal contrasts: FAT $=$ control versus SFA + EFA; FAS $=$ EFA versus SFA; MR $=$ LLA versus HLA. Effect of age was $P \leq 0.06$ for all dependent variables 新 except GMFI of CD18 and percentage of CD62L+. 


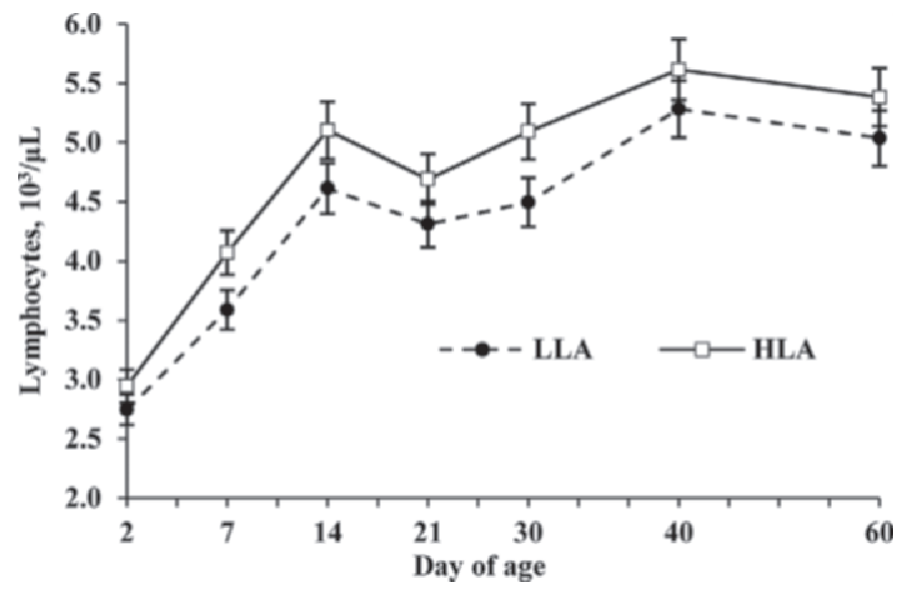

Figure 3. Blood concentrations of lymphocytes in Holstein calves fed milk replacer containing low linoleic acid (LLA) or high linoleic acid (HLA) from 0 to $60 \mathrm{~d}$ of age. Calves were born from cows fed diets supplemented with no fat (control), SFA, or essential FA starting at 8 wh before expected calving date. Grain was offered starting at $31 \mathrm{~d}$ of life. Effect of milk replacer: $P=0.05$; effect of age: $P<0.01$.

ferences between ruminant and nonruminant animals, and differences in age and physiological state.

Blood concentrations of platelets were within normal ranges reported for preweaned clinically healthy calves (Brun-Hansen et al., 2006). Concentrations increased dramatically during the first 2 wk of life before decreasing (effect of age: $P<0.01$; Figure 4 ), which is in agreement with Brun-Hansen et al. (2006). Decreased platelets during early postnatal period coincided with the period when diarrhea was most prevalent (i.e., during wk 2 of life). In addition to aiding the clotting process, Lam et al. (2011) reported that platelets enhanced transendothelial migration of neutrophils via glycoprotein ligands in mice. Indeed, blood concentrations of neutrophils were lower at d 14 compared with d 2 of life, which supports the proposition that the concentration of platelets increased at d 7 and 14 help enhance neutrophil migration to damaged tissues in calves experiencing diarrhea. Mean concentration of blood platelets was lower for calves fed HLA compared with those fed LLA MR $\left(715\right.$ vs. $801 \times 10^{3} / \mu \mathrm{L} ; P=$ 0.03). Some studies reported increased concentrations of blood platelets with development of various inflammatory diseases (Smyth et al., 2009); therefore, calves consuming HLA MR may have been experiencing less inflammation during the study.

\section{Acute-Phase Proteins and IFN- $Y$}

Concentrations of ASP in plasma were greatest immediately after calving $(\sim 230 \mathrm{mg} / \mathrm{L})$ and decreased gradually until plateauing at approximately $50 \mathrm{mg} / \mathrm{L}$ around $30 \mathrm{~d}$ of age (effect of age: $P<0.01$ ). Acid-solu-

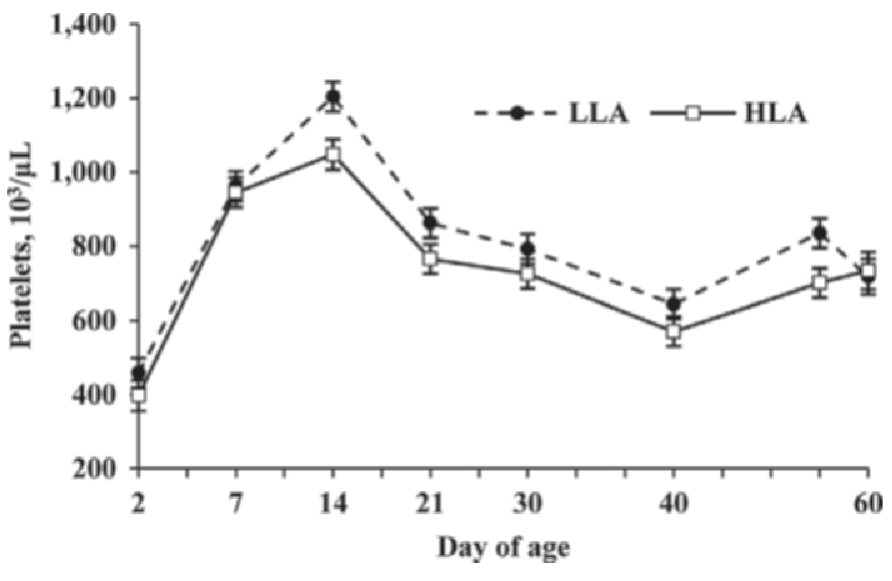

Figure 4. Blood concentrations of platelets in Holstein calves fed milk replacer containing low linoleic acid (LLA) or high linoleic acid (HLA) from 0 to $60 \mathrm{~d}$ of age. Calves were born from cows fed diets supplemented with no fat (control), SFA, or essential FA starting at 8 wh before expected calving date. Grain was offered starting at $31 \mathrm{~d}$ of life. Effect of milk replacer: $P=0.02$; effect of age: $P<0.01$.

ble protein has dual inflammatory and immunomodulatory properties. One of the mechanisms by which ASP can exert its antiinflammatory effects is by inhibiting platelet aggregation and, hence, platelet recruitment (Hochepied et al., 2003). Mean concentration of ASP in plasma was less in calves fed HLA MR compared with that of calves fed LLA (78.4 vs. $91.3 \mathrm{mg} / \mathrm{L} ; P<0.01$; Table 8). This response to MR is in harmony with the lower concentration of platelets in plasma (Table 7) and may be indicative of a protective mechanism.

Plasma Hp was absent or present in very low concentrations in healthy calves but its concentration increased in the presence of subclinical inflammation (Gånheim et al., 2007). When calves had gastroenteritis (Deignan et al., 2000) or viral respiratory infection (Heegaard et al., 2000), concentrations of Hp in plasma increased compared with healthy calves. In the current study, calves born from dams fed fat tended to have increased mean concentrations of $\mathrm{Hp}$ in plasma (0.97 vs. 0.90 optical density $\times 100 ; P=0.07)$ compared with calves born from dams fed the control diet, with concentrations peaking around $9 \mathrm{~d}$ of age (effect of age: $P<0.01$; Figure 5). However, Hp concentrations were not different between calves classified as having or not having diarrhea in the first $16 \mathrm{~d}$ of life. Based upon Hp concentrations, feeding fat prepartum appeared to slightly increase inflammation of calves during the preweaning period, although this increase was accompanied by increased BW gain by calves born from dams fed the SFA supplement.

One indicator of a developing immune system in neonatal calves is the shift from a reliance on $\mathrm{T}$ helper (Th) 2 cells to Th 1 cells (Chase et al., 2008). Because 


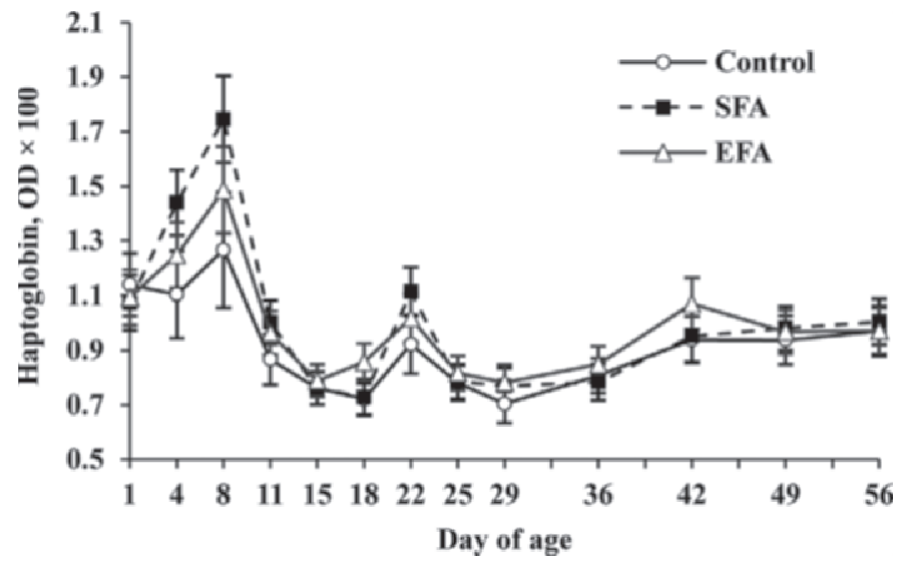

Figure 5. Plasma concentration of haptoglobin in Holstein calves fed milk replacer containing low linoleic acid or high linoleic acid from 1 to $60 \mathrm{~d}$ of age. Calves were born from cows fed diets supplemented with no fat (control), SFA, or essential FA (EFA) starting at $8 \mathrm{wk}$ before expected calving date. Grain was offered starting at $31 \mathrm{~d}$ of life. Effect of fat: $P=0.07$; effect of age: $P<0.01$. OD $=$ optical density.

the cytokine IFN- $\gamma$ is produced by Th 1 cells, earlier production of IFN- $\gamma$ can signal earlier maturation of the immune system. Interferon- $\gamma$ has potent antiviral activity, enhances antigen presentation, and influences leukocyte trafficking and leukocyte endothelial interaction (Chen and Liu, 2009). Stimulating PBMC with concanavalin A from 15-d old calves born from dams fed the SFA supplement tended to increase differential production of IFN- $\gamma$ compared with calves born from dams fed the EFA supplement (44.1 vs. $23.3 \mathrm{pg} / \mathrm{mL} ; P$ $=0.08$; Table 8 ). This result might indicate a favorable early switching from a Th 2- to a Th 1-meditated immune response in calves born from dams fed the SFA supplement. This preferential production of IFN- $\gamma$ at $15 \mathrm{~d}$ continued numerically at $30 \mathrm{~d}$ of age. In vitro production of IFN- $\gamma$ by stimulated PBMC was correlated positively with the concentration of $\mathrm{C} 18: 0$ in the PBMC of human subjects (Kew et al., 2003). At $30 \mathrm{~d}$ of age, calves fed the HLA MR had a greater differential production of IFN- $\gamma$ compared with calves fed the LLA MR (48.1 vs. $25.6 \mathrm{pg} / \mathrm{mL} ; P=0.05$ ). This increased production of IFN- $\gamma$ by stimulated PBMC in these 2 groups of calves matched well with increased growth by these 2 groups (Table 5). In vitro production of IFN- $\gamma$ by pokeweed mitogen-stimulated PBMC was increased at $18 \mathrm{~d}$ of life when Holstein bull calves consumed a $30 \%$ CP MR at $2.5 \%$ of BW compared with those offered a $20 \%$ CP MR consumed at $1.4 \%$ of BW (Nonnecke et al., 2003) . Growth rate also was greater for those calves consuming more nutrients. In a follow-up study, differential production of IFN- $\gamma$ by PBMC stimulated with Mycobacterium bovis strain bacillus CalmetteGuérin or ovalbumin was not increased at 3 and 5 wk 
of life in faster-growing calves fed more MR of the same nutrient content (Foote et al., 2007). Lastly, production of IFN- $\gamma$ by mononuclear cell cultures stimulated with concanavalin A or phytohemagglutinin $\mathrm{P}$ from dairy calves differing in ADG did not differ (Ballou, 2012). Taken together, growth rate by itself may not affect IFN- $\gamma$ production by PBMC. However, linoleic acid can increase proinflammatory cytokine production. Human PBMC stimulated with LPS produced 62 and $47 \%$ more IL-1 and tumor necrosis factor, respectively when the diet was modified to increase intake of linoleic acid (Meydani et al., 1993). Replacing some CCO with porcine lard in calf MR appeared to affect the immune status, as evidenced by changes in some blood cell populations, circulating concentrations of ASP, and in vitro production of IFN- $\gamma$ by PBMC. These changes may have been due to increasing intake of linoleic acid.

\section{CONCLUSIONS}

Supplementation of FA enriched in SFA or EFA to pregnant, nonlactating dams (1.7\% of dietary DM) and to preweaned Holstein calves (17\% of MR DM) changed FA status of the calf. Prepartum supplementation of dried fat enriched in SFA tended to improve intake of grain from 31 to $60 \mathrm{~d}$ of life and improved ADG of calves without changing concentrations of IGF-1 in plasma during the 60-d study compared with calves born from dams supplemented with EFA prepartum. Partially replacing $\mathrm{CCO}$ with porcine lard in the MR increased intake of linoleic acid from 2.4 to $8.0 \mathrm{~g} / \mathrm{d}$ and $\alpha$-linolenic acid from 0 to $0.7 \mathrm{~g} / \mathrm{d}$ during the first 30 $\mathrm{d}$ of life, resulting in increased plasma concentrations of glucose and IGF-I and influencing the function and composition of some blood cell populations toward a more active proinflammatory response. All these metabolic and immune responses were associated with an improved ADG and FE. Dam diet had little influence on effects of MR on calf performance or blood components. Further studies are warranted to examine the mechanisms by which linoleic acid enhances anabolic activity and promotes the proinflammatory response of immune cells of preweaned calves.

\section{ACKNOWLEDGMENTS}

The help of the entire staff at the University of Florida Dairy Research Unit (Gainesville) is appreciated deeply. Graduate students Leonardo Martins, Fabio Lima, and Eduardo Ribeiro provided valuable help with field activities. Arm and Hammer Nutrition (Princeton, NJ) is gratefully acknowledged for partial funding of the study.

\section{REFERENCES}

Allen, R. E., L. S. Luiten, and M. V. Dodson. 1985. Effect of insulin and linoleic acid on satellite cell differentiation. J. Anim. Sci. 60:1571-1579.

Badinga, L., R. J. Collier, W. W. Thatcher, C. J. Wilcox, H. H. Head, and F. W. Bazer. 1991. Ontogeny of hepatic bovine growth hormone receptors in cattle. J. Anim. Sci. 69:1925-1934.

Ballou, M. A. 2012. Immune responses of Holstein and Jersey calves during the preweaning and immediate postweaned periods when fed varying planes of milk replacer. J. Dairy Sci. 95:7319-7330.

Ballou, M. A., G. D. Cruz, W. Pittroff, D. H. Keisler, and E. J. DePeters. 2008. Modifying the acute phase response of Jersey calves by supplementing milk replacer with omega-3 fatty acids from fish oil. J. Dairy Sci. 91:3478-3487.

Ballou, M. A., and E. J. DePeters. 2008. Supplementing milk replacer with omega-3 fatty acids from fish oil on immunocompetence and health of Jersey calves. J. Dairy Sci. 91:3488-3500.

Banta, J. P., D. L. Lalman, F. N. Owens, C. R. Krehbiel, and R. P. Wettemann. 2011. Effects of prepartum supplementation of linoleic and mid-oleic sunflower seed on cow performance, cow reproduction, and calf performance from birth through slaughter, and effects on intake and digestion in steers. J. Anim. Sci. 89:37183727 .

Bauchart, D., and B. Aurousseau. 1981. Postprandial lipids in blood plasma of preruminant calves. J. Dairy Sci. 64:2033-2042.

Bradbury, J. 2011. Docosahexaenoic acid (DHA): An ancient nutrient for the modern human brain. Nutrients 3:529-554.

Brun-Hansen, H. C., A. H. Kampen, and A. Lund. 2006. Hematological values in calves during the first six months of life. Vet. Clin. Pathol. 35:182-187.

Burr, G. O., and M. M. Burr. 1930. On the nature and rôle of the fatty acids essential in nutrition. J. Biol. Chem. 86:587-621.

Calder, P. C. 2005. Polyunsaturated fatty acids and inflammation. Biochem. Soc. Trans. 33:423-427.

Calder, P. C. 2012. Mechanisms of action of (n-3) fatty acids. J. Nutr. 142:592S-599S.

Calder, P. C., J. A. Bond, D. J. Harvey, S. Gordon, and E. A. Newsholme. 1990. Uptake and incorporation of saturated and unsaturated fatty acids into macrophage lipids and their effect upon macrophage adhesion and phagocytosis. Biochem. J. 269:807-814.

Chase, C. C. L., D. J. Hurley, and A. J. Reber. 2008. Neonatal immune development in the calf and its impact on vaccine response. Vet. Clin. North Am. Food Anim. Pract. 24:87-104.

Chechi, K., and S. K. Cheema. 2006. Maternal diet rich in saturated fats has deleterious effects on the plasma lipids of mice. Exp. Clin. Cardiol. 11:129-135.

Chen, J., and X. Liu. 2009. The role of interferon gamma in regulation of $\mathrm{CD} 4^{+} \mathrm{T}$-cells and its clinical implications. Cell. Immunol. 254:85-90.

Cho, H. P., M. T. Nakamura, and S. D. Clarke. 1999. Cloning, expression, and nutritional regulation of the mammalian $\Delta-6$ desaturase. J. Biol. Chem. 274:471-477.

Colditz, I. G. 2002. Effects of the immune system on metabolism: Implications for production and disease resistance in livestock. Livest. Prod. Sci. 75:257-268.

Cunnane, S. C., and P. Guesnet. 2011. Linoleic acid recommendations: A house of cards. Prostaglandins Leukot. Essent. Fatty Acids 85:399-402.

Daniels, K. M., S. R. Hill, K. F. Knowlton, R. E. James, M. L. McGilliard, and R. M. Akers. 2008. Effects of milk replacer composition on selected blood metabolites and hormones in preweaned Holstein heifers. J. Dairy Sci. 91:2628-2640.

Deignan, T., A. Alwan, J. Kelly, J. McNair, T. Warren, and C. O'Farrelly. 2000. Serum haptoglobin: An objective indicator of experimentally-induced Salmonella infection in calves. Res. Vet. Sci. 69:153-158.

Drackley, J. K. 2005. Interorgan lipid and fatty acid metabolism in growing ruminants. Pages 323-350 in Biology of Metabolism in Growing Animals. D. G. Burrin and H. J. Mersmann, ed. Elsevier Limited, Edinburgh, UK. 
Duval, C., M. Müller, and S. Kersten. 2007. PPAR $\alpha$ and dyslipidemia. Biochim. Biophys. Acta 1771:961-971.

EFSA Panel on Dietetic Products, Nutrition, and Allergies (NDA). 2010. Scientific opinion on dietary reference values for fats, including saturated fatty acids, polyunsaturated fatty acids, monounsaturated fatty acids, trans fatty acids, and cholesterol. EFSA J. 8:1461. 10.2903/j.efsa.2010.1461.

Fernandez, M. L., and K. L. West. 2005. Mechanisms by which dietary fatty acids modulate plasma lipids. J. Nutr. 135:2075-2078.

Foote, M. R., B. J. Nonnecke, D. C. Beitz, and W. R. Waters. 2007. High growth rate fails to enhance adaptive immune responses of neonatal calves and is associated with reduced lymphocyte viability. J. Dairy Sci. 90:404-417.

Gånheim, C., S. Alenius, and K. Persson Waller. 2007. Acute phase proteins as indicators of calf herd health. Vet. J. 173:645-651.

Garcia, M., L. F. Greco, M. G. Favoreto, R. S. Marsola, L. T. Martins, R. S. Bisinotto, J. H. Shin, A. L. Lock, E. Block, W. W. Thatcher, J. E. P. Santos, and C. R. Staples. 2014. Effect of supplementing fat to pregnant nonlactating cows on colostral fatty acid profile and passive immunity of the newborn calf. J. Dairy Sci. 97:392405.

Gibson, R. A., B. Muhlhausler, and M. Makrides. 2011. Conversion of linoleic acid and alpha-linolenic acid to long-chain polyunsaturated fatty acids (LCPUFAs), with a focus on pregnancy, lactation and the first 2 years of life. Matern. Child Nutr. 7:17-26.

Gochman, N., and J. M. Schmitz. 1972. Application of a new peroxide indicator reaction to the specific automated determination of glucose with glucose oxidase. Clin. Chem. 18:943-950.

Heegaard, P. M. H., D. L. Godson, M. J. M. Toussaint, K. Tjørnehøj, L. E. Larsen, B. Viuff, and L. Rønsholt. 2000. The acute phase response of haptoglobin and serum amyloid A (SAA) in cattle undergoing experimental infection with bovine respiratory syncytial virus. Vet. Immunol. Immunopathol. 77:151-159.

Hill, S. R., K. F. Knowlton, K. M. Daniels, R. E. James, R. E. Pearson, A. V. Capuco, and R. M. Akers. 2008. Effects of milk replacer composition on growth, body composition, and nutrient excretion in preweaned Holstein heifers. J. Dairy Sci. 91:3145-3155.

Hochepied, T., F. G. Berger, H. Baumann, and C. Libert. 2003. $\alpha_{1^{-}}$ Acid glycoprotein: An acute phase protein with inflammatory and immunomodulating properties. Cytokine Growth Factor Rev. 14:25-34.

Holman, R. T. 1978. How essential are essential fatty acids? J. Am. Oil Chem. Soc. 55:774A-781A.

Holman, R. T., S. B. Johnson, and P. L. Ogburn. 1991. Deficiency of essential fatty acids and membrane fluidity during pregnancy and lactation. Proc. Natl. Acad. Sci. USA 88:4835-4839.

Huuskonen, A., H. Khalili, J. Kiljala, E. Joki-Tokola, and J. Nousiainen. 2005. Effects of vegetable fats versus lard in milk replacers on feed intake, digestibility, and growth in Finnish Ayrshire bull calves. J. Dairy Sci. 88:3575-3581.

Igarashi, M., K. Ma, L. Chang, J. M. Bell, and S. I. Rapoport. 2007. Dietary n-3 PUFA deprivation for 15 weeks upregulates elongase and desaturase expression in rat liver but not brain. J. Lipid Res. 48:2463-2470.

Jacobi, S. K., and J. Odle. 2012. Nutritional factors influencing intestinal health of the neonate. Adv. Nutr. 3:687-696.

Jenkins, K. J., and J. K. G. Kramer. 1986. Influence of low linoleic and linolenic acids in milk replacer on calf performance and lipids in blood plasma, heart, and liver. J. Dairy Sci. 69:1374-1386.

Jenkins, K. J., J. K. G. Kramer, F. D. Sauer, and D. B. Emmons. 1985. Influence of triglycerides and free fatty acids in milk replacers on calf performance, blood plasma, and adipose lipids. J. Dairy Sci. 68:669-680.

Johnson, M. M., and J. P. Peters. 1993. Technical note: An improved method to quantify nonesterified fatty acids in bovine plasma. J. Anim. Sci. 71:753-756.

Kampen, A. H., I. Olsen, T. Tollersrud, A. K. Storset, and A. Lund. 2006. Lymphocyte subpopulations and neutrophil function in calves during the first 6 months of life. Vet. Immunol. Immunopathol. 113:53-63.
Kenward, M. G., and J. H. Roger. 1997. Small sample inference for fixed effects from the restricted maximum likelihood. Biometrics 53:983-997.

Kew, S., T. Banerjee, A. M. Minihane, Y. E. Finnegan, C. M. Williams, and P. C. Calder. 2003. Relation between the fatty acid composition of peripheral blood mononuclear cells and measures of immune cell function in healthy, free-living subjects aged 25-72 y. Am. J. Clin. Nutr. 77:1278-1286.

Kramer, J. K. G., V. Fellner, M. E. R. Dugan, F. D. Sauer, M. M. Mossoba, and M. P. Yurawecz. 1997. Evaluating acid and base catalysts in the methylation of milk and rumen fatty acids with special emphasis on conjugated dienes and total trans fatty acids. Lipids 32:1219-1228.

Laarman, A. H., A. L. Ruiz-Sanchez, T. Sugino, L. L. Guan, and M. Oba. 2012. Effects of feeding a calf starter on molecular adaptations in the ruminal epithelium and liver of Holstein dairy calves. J. Dairy Sci. 95:2585-2594.

Lake, S. L., E. J. Scholljegerdes, R. L. Atkinson, V. Nayigihugu, S. I. Paisley, D. C. Rule, G. E. Moss, T. J. Robinson, and B. W. Hess. 2005. Body condition score at parturition and postpartum supplemental fat effects on cow and calf performance. J. Anim. Sci. 83:2908-2917.

Lake, S. L., E. J. Scholljegerdes, D. M. Hallford, G. E. Moss, D. C, Rule, and B. W. Hess. 2006a. Body condition score at parturition and postpartum supplemental fat effects on metabolite and hormone concentrations of beef cows and their suckling calves. J. Anim. Sci. 84:1038-1047.

Lake, S. L., E. J. Scholljegerdes, T. R. Weston, D. C. Rule, and B. W. Hess. 2006b. Postpartum supplemental fat, but not maternal body condition score at parturition, affects plasma and adipose tissue fatty acid profiles of suckling beef calves. J. Anim. Sci. 84:1811-1819.

Lam, F. W., A. R. Burns, C. W. Smith, and R. E. Rumbaut. 2011. Platelets enhance neutrophil transendothelial migration via P-selectin glycoprotein ligand-1. Am. J. Physiol. Heart Circ. Physiol. 300:H468-H475.

Le Roith, D., C. Bondy, S. Yakar, J.-L. Liu, and A. Butler. 2001. The somatomedin hypothesis: 2001. Endocr. Rev. 22:53-74.

Li, T., and J. Y. Chiang. 2009. Regulation of bile acid and cholesterol metabolism by PPARs. PPAR Res. 2009:501739. http://dx.doi. org $/ 10.1155 / 2009 / 501739$

Loor, J. J., and J. H. Herbein. 2003. Reduced fatty acid synthesis and desaturation due to exogenous trans10,cis12-CLA in cows fed oleic or linoleic oil. J. Dairy Sci. 86:1354-1369.

Magalhães, V. J. A., F. Susca, F. S. Lima, A. F. Branco, I. Yoon, and J. E. P. Santos. 2008. Effect of feeding yeast culture on performance, health, and immunocompetence of dairy calves. J. Dairy Sci. 91:1497-1509.

Makimura, S., and N. Suzuki. 1982. Quantitative determination of bovine serum haptoglobin and its elevation in some inflammatory diseases. Nippon Juigaku Zasshi 44:15-21.

Marsh, W. H., B. Fingerhut, and H. Miller. 1965. Automated and manual direct methods for the determination of blood urea. Clin. Chem. 11:624-627.

Meydani, S. N., A. H. Lichtenstein, S. Cornwall, M. Meydani, B. R. Goldin, H. Rasmussen, C. A. Dinarello, and E. J. Schaefer. 1993. Immunologic effects of national cholesterol education panel step-2 diets with and without fish-derived N-3 fatty acid enrichment. J. Clin. Invest. 92:105-113.

Murley, W. R., N. L. Jacobson, G. H. Wise, and R. S. Allen. 1949. Filled milks for dairy calves. II. Comparative effects of various types of soybean oils and of butter oil on health, growth and certain blood constituents. J. Dairy Sci. 32:609-619.

Nonnecke, B. J., M. R. Foote, J. M. Smith, B. A. Pesch, and M. E. Van Amburgh. 2003. Composition and functional capacity of blood mononuclear leukocyte populations from neonatal calves on standard and intensified milk replacer diets. J. Dairy Sci. $86: 3592-3604$.

NRC. 1995. Nutrient Requirements for Laboratory Animals. 4th rev. ed. Natl. Acad. Sci., Washington, DC. 
Osorio, J. S., E. Trevisi, M. A. Ballou, G. Bertoni, J. K. Drackley, and J. J. Loor. 2013. Effect of the level of maternal energy intake prepartum on immunometabolic markers, polymorphonuclear leukocyte function, and neutrophil gene network expression in neonatal Holstein heifer calves. J. Dairy Sci. 96:3573-3587.

Padua, M. B., and P. J. Hansen. 2008. Regulation of DNA synthesis and the cell cycle in human prostate cancer cells and lymphocytes by ovine uterine serpin. BMC Cell Biol. 9:5.

Quigley, J. D., T. A. Wolfe, and T. H. Elsasser. 2006. Effects of additional milk replacer feeding on calf health, growth, and selected blood metabolites in calves. J. Dairy Sci. 89:207-216.

Rodrigues, H. G., M. A. Ramirez Vinolo, J. Magdalon, H. Fujiwara, D. M. H. Cavalcanti, S. H. P. Farsky, P. C. Calder, E. Hatanaka, and R. Curi. 2010. Dietary free oleic and linoleic acid enhances neutrophil function and modulates the inflammatory response in rats. Lipids 45:809-819.

SAS Institute. 2009. SAS/STAT 9.2 User's Guide. SAS Inst. Inc., Cary, NC.

Sato, H. 1994. Plasma ketone levels in neonatal calves fed medium chain triglycerides in milk. J. Vet. Med. Sci. 56:781-782.

Schiaffino, S., K. A. Dyar, S. Ciciliot, B. Blaauw, and M. Sandri. 2013. Mechanisms regulating skeletal muscle growth and atrophy. FEBS J. 280:4294-4314.
Silvestre, F. T., T. S. M. Carvalho, P. C. Crawford, J. E. P. Santos, C. R. Staples, T. Jenkins, and W. W. Thatcher. 2011. Effects of differential supplementation of fatty acids during the peripartum and breeding periods of Holstein cows: II. Neutrophil fatty acids and function, and acute phase proteins. J. Dairy Sci. 94:2285-2301.

Simon, S. I., Y. Hu, D. Vestweber, and C. W. Smith. 2000. Neutrophil tethering on E-selectin activates $\beta_{2}$ integrin binding to ICAM-1 through a mitogen-activated protein kinase signal transduction pathway. J. Immunol. 164:4348-4358.

Smith, J. M., M. E. Van Amburgh, M. C. Diaz, M. C. Lucy, and D. E. Bauman. 2002. Effect of nutrient intake on the development of the somatotropic axis and its responsiveness to $\mathrm{GH}$ in Holstein bull calves. J. Anim. Sci. 80:1528-1537.

Smyth, S. S., R. P. McEver, A. S. Weyrich, C. N. Morrell, M. R. Hoffman, G. M. Arepally, P. A. French, H. L. Dauerman, and R. C Becker. 2009. Platelet functions beyond hemostasis. J. Thromb. Haemost. 7:1759-1766.

Tyler, J. W.. D. D. Hancock, S. M. Parish, D. E. Rea, T. E. Besser, S. G. Sanders, and L. K. Wilson. 1996. Evaluation of 3 assays for failure of passive transfer in calves. J. Vet. Intern. Med. 10:304-307. 